Law \& Economics Working Papers

Law \& Economics Working Papers Archive:

2003-2009

University of Michigan Law School

Year 2007

\title{
The Rise and Fall of Arm's Length: A Study in the Evolution of U.S. International Taxation
}

Reuven S. Avi-Yonah

University of Michigan Law School, aviyonah@umich.edu 


\title{
THE RISE AND FALL OF ARM'S LENGTH: A STUDY IN THE EVOLUTION OF U.S. INTERNATIONAL TAXATION
}

\author{
Reuven S. Avi-Yonah ${ }^{1}$
}

\section{INTRODUCTION}

In 1988, the U.S. Treasury Department published a study of intercompany pricing, the "White Paper," that included the following endorsement of the so-called arm's length standard (henceforth, the "ALS") for examining the reasonableness of transactions between related parties for tax purposes:

The arm's length standard is embodied in all U.S. tax treaties; it is in each major model treaty, including the U.S. Model Convention; it is incorporated into most tax treaties to which the United States is not a party; it has been explicitly adopted by international organizations that have addressed themselves to transfer pricing issues; and virtually every major industrial nation takes the arm's length standard as its frame of reference in transfer pricing cases. . . The United States should continue to adhere to the arm's length standard. n1

What is the ALS, and why did the Treasury seek to defend it in these terms? The problem for which the ALS attempts to provide the solution may be illustrated by a simple example. Suppose that a product (e.g., computers) is manufactured by a corporation in country A, and then sold to a wholly owned subsidiary of the manufacturer in country $\mathrm{B}$, which proceeds to resell it to unrelated customers. In this common situation, the taxable profit of the subsidiary is determined by three factors: (1) the price at which it resells the computers to the unrelated customers, (2) its expenses other than cost of goods sold, and (3) the price which it pays its parent corporation for the computers. The first two of these factors are governed by market forces outside the control of the parent or the subsidiary. However, because the parent controls the subsidiary, the third factor (the price for which the manufacturer sells the computers to the reseller, or the "transfer price") is wholly within the control of the related parties. Accordingly, the potential for abuse arises because the related parties will seek to increase aftertax profits by manipulating the transfer price. If the effective tax rate in the manufacturer's country is higher, the price will be set as low as possible so as to channel all taxable profit to the reseller. Conversely, if the effective tax rate in the reseller's jurisdiction is higher, the transfer price will be as high as possible, so as to eliminate any taxable profit of the reseller and concentrate the entire profit in the hands of the manufacturer. But for tax considerations, the affiliated parties do not care what the transfer price is, since it merely reallocates profits within the affiliated group.

Given these facts, it is understandable that transfer pricing manipulation is one of the most common techniques of tax avoidance. This is especially true in the international sphere, as there are great differences in effective tax rates among jurisdictions. Indeed, some economists have argued that the ability to manipulate transfer prices is a major reason for the existence of multi-national enterprises, which are groups of affiliated corporations operating in more than one country. n2 It is estimated that trading among such affiliates encompasses about one third of world manufacturing trade, $\mathrm{n} 3$ and that percentage is constantly increasing. The transfer pricing problem is, therefore, one of the major international tax policy challenges for the coming century.

The ALS, as traditionally conceived, responds to the transfer pricing problem by seeking to determine whether transactions between related taxpayers reflect their "true" tax liability by comparing them to similar transactions

\footnotetext{
${ }^{1}$ Irwin I. Cohn Professor of Law and Director, International Tax LLM Program, the University of Michigan Law School. The first part of this article is based on an article by the same name in the Virginia Tax Review, 15 Va. Tax
} Rev. 89 (1995). 
between unrelated taxpayers dealing at arm's length. This was the definition of the ALS that was understood when the White Paper was published in 1988. n4 However, as is reflected in the defensive tone of the Treasury's pronouncements, the White Paper was written at a time when this traditional conception of the ALS was coming under increasing criticism and suggestions for its replacement were rampant. In particular, the legislative history of the Tax Reform Act of 1986 indicates that Congress had mandated that the Treasury Department reevaluate the continued viability of the ALS. n5 The White Paper was issued in response to this mandate. However, despite Treasury's findings, the process begun by the Congressional mandate eventually resulted in the abandonment of the ALS, as it was understood in 1988. Its replacement, in the United States and elsewhere, was a broader and more flexible method of determining the allocation of taxable profits between related entities. Although this broader method may also be characterized as 'arm's length," it is a different type of arm's length standard than the one defended by the White Paper. Indeed, the White Paper itself played a major part in the demise of the traditional ALS.

This Article explores the process by which the traditional ALS became the dominant method for determining transfer prices for tax purposes, the reasons for its eventual downfall, and methods that can be used in its place. First, a few definitional points are in order. The traditional ALS refers primarily to a process by which the transfer price between affiliated taxpayers is determined by using comparables -- either of the same product sold by one of the affiliated parties to an unrelated party, of the same product bought by an affiliated party from an unrelated party, or of the same product sold between two parties unrelated to the affiliated parties and to each other. This method of comparison is usually called the "comparable uncontrolled price," or CUP method. n6 In addition, the traditional ALS also encompasses two methods that likewise rely on comparables, but do not require a transaction in the same product. Under the "cost plus" method, the transfer price is determined by comparing the manufacturer to a similar entity (under a more relaxed standard of comparability than under the CUP method), which is dealing with unrelated parties, and allocating to the manufacturer the costs borne by the unrelated comparable, plus the unrelated party's profit margin. n7 The "resale price" method is identical to the cost plus method except that it applies to the reseller rather than the manufacturer. n8

The ALS, as traditionally conceived, is frequently contrasted with "unitary", "global" or "formulary apportionment" methods, such as those used by some states. Here the entire profit of an affiliated group is allocated among its constituent entities by means of a formula (e.g., based on each entity's assets, payroll and sales). n9 The major difference between the ALS and the formulary method is that the ALS starts with treating each entity in an affiliated group as a separate taxpayer, hypothetically dealing with each other entity in the group at arm's length. Conversely, the formulary approach starts with the entire affiliated group as one unitary enterprise.

This article proposes that despite the common practice of contrasting the ALS and the formulary methods of dealing with the transfer pricing problem, they are actually not dichotomous. Instead, they form the two extreme ends of a continuum. n10 The cost plus and resale price methods, which are included in the traditional ALS, already represent one step away from pure separate treatment of each entity in the group. This is because they involve taking the group's profits as a whole, subtracting the profit margin allocable to the manufacturer or the reseller on the basis of the comparables, and then allocating the residual profit to the other party.

Next on the continuum comes the "comparable profit method" (CPM), which is a major innovation of the recent regulations under Section 482 of the Internal Revenue Code ("the Code"), under which the profit of either the manufacturer or the reseller is set by comparing it to the average profit earned by a very broad group of corporations operating in the same or a similar industry. n11 The standard of comparison in this case is very relaxed, and one may indeed regard the CPM as a type of formula designed to ensure that the profits of the related party do not fall outside a reasonable range of profit margins earned by other corporations which are not truly comparable with the related party. n12 As will be shown below, the CPM falls outside the traditional or narrow definition of the ALS, but it still uses some form of comparables.

Even further along on the continuum of possible methods of determining transfer prices is the "profit split" method. This method was first introduced in the 1988 White Paper. n13 Here, the allocation of profits is determined in two steps. First, the functions performed by each of the related parties are analyzed and a market rate of return is allocated to each function on the basis of comparables. n14 Then, the residual profit is split between the related parties on the basis of a formula, without using comparables. $\mathrm{n} 15$ The profit split method is very close to the pure formulary apportionment end of the transfer pricing continuum, because it starts with the enterprise as a whole and allocates the profits in a formulary fashion. The only differences are that some of the profits are allocated on the basis of 
comparables, and that the formula used to split the rest is more flexible than the traditional assets, payroll and salesbased formula used by the states.

Consequently, the words "arm's length" can be used in two ways to refer to two different possible ranges of solutions to the transfer pricing problem. Under the traditional or narrow definition, "arm's length" refers to methods of determining transfer prices by using comparables, and encompasses only the CUP, cost plus and resale price methods. n16 On the other hand, "arm's length" can also be used to refer to any method of determining transfer prices that reaches results (i.e., a profit allocation) that are the same as those that would have been reached between unrelated parties. In this latter, broader sense, "arm's length" can be used to refer to the entire transfer pricing continuum, because even pure formulary apportionment may result in the same profit allocation as that which unrelated parties would have reached.

The first four parts of this Article analyze the origins, rise, decline and fall of the traditional or narrow ALS, as applied to international transactions between related parties under section 482 of the Code and its predecessors. n17 The analysis will show that despite the Treasury's affirmation of the traditional ALS in its 1988 White Paper, n18 this narrow conception of the standard was already obsolete by 1988 in the large majority of cases, insofar as the United States' approach to international taxation was concerned. Subsequent developments, especially the recently issued proposed, temporary and final regulations under section 482 of the Code, merely strengthened the nails in its coffin. The last section of the Article will focus on the following questions: (1) why has the traditional ALS proven so inadequate, (2) what methods are now used to supplement it, and (3) what additional improvements can be made in resolving the transfer pricing problem?

\section{ORIGINS}

Transfer pricing manipulation is one of the simplest ways to avoid taxation. It is, thus, not surprising that the predecessors of section 482 of the Code, legislation designed to combat such manipulation, date back almost as far as the modern income tax itself. They originated in Regulation 41, Articles 77 and 78, of the War Revenue Act of 1917, which gave the Commissioner authority to require related corporations to file consolidated returns "whenever necessary to more equitably determine the invested capital or taxable income." n19 The earliest direct predecessor of section 482 of the Code dates to 1921, when the Commissioner was authorized to consolidate the accounts of affiliated corporations "for the purpose of making an accurate distribution or apportionment of gains, profits, income, deductions, or capital between or among such related trades or business." n20 This legislation was enacted, in part, because of the tax avoidance opportunities afforded by possessions corporations, which were ineligible to file consolidated returns with their domestic affiliates. n21 Thus, the problem of international tax avoidance through related corporations was one of the original motives for the enactment of the earliest predecessor of section 482 of the Code. n22

In 1928, the provision was removed from the consolidated return provisions (which were eliminated) and expanded to read as follows:

Section 45. Allocation of Income and Deductions.

In any case of two or more trades or businesses (whether or not incorporated, whether or not organized in the United States, and whether or not affiliated) owned or controlled directly or indirectly by the same interests, the Commissioner is authorized to distribute, apportion, or allocate gross income or deductions between or among such trades or businesses, if he determines that such distribution, apportionment, or allocation is necessary in order to prevent evasion of taxes or clearly to reflect the income of any of such trades or businesses. n23

This language is almost identical to section 482 of the Code as it read prior to the Tax Reform Act of 1986 . n24

The legislative history of Section 45 of the Code, in its entirety, is as follows: 
Section 45 is based upon section 240(f) of the 1926 Act, broadened considerably in order to afford adequate protection to the Government made necessary by the elimination of the consolidated return provisions of the 1926 Act. The section of the new bill provides that the Commissioner may, in the case of two or more trades or businesses owned or controlled by the same interests, apportion, allocate, or distribute the income or deductions between or among them, as may be necessary in order to prevent evasion (by the shifting of profits, the making of fictitious sales, and other methods frequently adopted for the purpose of "milking"), and in order clearly to reflect their true tax liability. n25 Senator Gifford stated on the floor that "what worries us is that any two of these corporations can get together and take advantage of questionable sales to each other to get deductions." n26 Senator Green replied that "Section 45. . .permits the bureau to allocate the income where it belongs. It. . .does not permit these corporations to place the expenses just where they want to put them." n27

Congress' focus in enacting the predecessor of section 482 of the Code was, thus, to prevent tax evasion and to clearly reflect "true" tax liability. However, there was no discussion of what the standard of "true" liability was. In 1935, the Service issued regulations under section 45 of the Code, which stated that the following standards would govern its application:

(b) Scope and purpose. -- The purpose of section 45 is to place a controlled taxpayer on a tax parity with an uncontrolled taxpayer, by determining, according to the standard of an uncontrolled taxpayer, the true net income from the property and business of a controlled taxpayer. The interests controlling a group of controlled taxpayers are assumed to have complete power to cause each controlled taxpayer so to conduct its affairs that its transactions and accounting records truly reflect the net income from the property and business of each of the controlled taxpayers. If, however, this has not been done, and the taxable net incomes are thereby understated, the statute contemplates that the Commissioner shall intervene, and, by making such distributions, apportionments, or allocations as he may deem necessary of gross income or deductions, or of any item or element affecting net income, between or among the controlled taxpayers constituting the group, shall determine the true net income of each controlled taxpayer. The standard to be applied in every case is that of an uncontrolled taxpayer dealing at arm's length with another uncontrolled taxpayer. n28

Thus, the ALS, under U.S. tax law, was born. This section of the regulations, in very similar language, remained in effect under section 482 of the Code until the recently-issued modifications. n29

However, the regulations were not modified to explain what methods should be used to arrive at an arm's length price until 1968. Previously, this task was left to the courts.

\section{RISE}

The early cases applying section 45 of the Code did not mention the ALS. Instead, they focused on the statutory terms "evasion of taxes" and "clear reflection of income." n30 It was not until the 1935 regulations were issued, that the arm's length nature of the transaction between related parties came into focus. n31 However, for a long period thereafter, the courts applied a wide variety of standards to determine what constituted a transaction that clearly reflected the taxpayer's income. n32

Seminole Flavor Co. v. Commissioner n33 is a good example of these early cases. The issue was whether transactions between a corporation and a partnership organized to market the corporation's products should be adjusted to shift income from the partnership to the corporation. n34 The Tax Court, in holding for the taxpayer, stated that the arm's length nature of the transaction should be determined by whether it was "fair and reasonable," and that the question of whether unrelated parties would have entered into the same agreement was irrelevant. n35 It then went on to hold that- 
The commission fixed does not appear to be out of line with petitioner's own experience [i.e., its expenses for marketing prior to forming the partnership]. On this basis the transaction would seem to be fair and entitled to classification as an arm's length transaction. Whether any such business agreement would have been entered into by petitioner with total strangers is wholly

problematical. n36

Other cases from the same period show similar tendencies to apply a variety of standards and to ignore the question of whether comparables exist. The standards employed included whether the transaction was "fair" on the basis of the functions performed by the parties; n37 whether the related party paid "full fair value;" n38 and whether the prices paid would have been considered "fair and reasonable" in the trade. n39

On the other hand, in Hall v. Commissioner, n40 a somewhat later Tax Court case, a comparable was used to establish the arm's length price. Hall involved sales to a Venezuelan marketing affiliate at cost plus $10 \%$ (a price which amounted to a discount of over $90 \%$ from the regular list price) when unrelated distributors of the same product received a discount of only 20\%. n41 The Tax Court held that gross income had been arbitrarily shifted to the Venezuelan corporation, and that the Commissioner's allocation "reflected Hall's income as if he had been dealing with unrelated parties. That, of course, was the purpose of the statute." n42

The early cases, thus, appear inconsistent in their application of arm's length. The question of whether the ALS should always be applied was finally raised in Frank v. International Canadian Corporation, n43 decided in 1962, which was 27 years after the initial promulgation of the standard in regulations. n44 The case involved transfer prices for sales of chemicals by a U.S. parent to a Western Hemisphere Trade Corporation (WHTC). The parties stipulated that the sales reflected a "reasonable price and profit" between the two corporations, and the District Court found that the Commissioner had thereby stipulated himself out of court on the section 45 issue. n45 The Commissioner appealed, arguing that the District Court used the "reasonable return" standard instead of the proper arm's length standard. The Court of Appeals for the Ninth Circuit affirmed in the following terms:

We do not agree with the Commissioner's contention that "arm's length bargaining" is the sole criterion for applying the statutory language of section 45 in determining what the "true net income" is of each "controlled taxpayer." Many decisions have been reached under section 45 without reference to the phrase "arm's length bargaining" and without reference to Treasury Department Regulations and Rulings which state that the talismanic combination of words-"arm's length"-is the "standard to be applied in every case." For example, it was not any less proper for the District Court to use here the "reasonable return" standard than it was for other courts to use "full fair value," "fair price, including a reasonable profit," "method which seems not unreasonable," "fair consideration which reflects arm's length dealing," "fair and reasonable," "fair and reasonable" or "fair and fairly arrived at," or "judged as to fairness," all used in interpreting section 45 . n46

Thus, the Ninth Circuit essentially invalidated the regulations, and held that it was not necessary to establish what unrelated taxpayers would have done in order to clearly reflect the "true" income and correct tax liability of related parties. $\mathrm{n} 47$

One can only speculate as to what would have happened had the courts been left free to develop their own definition of "fair" or "reasonable" without having to adhere to the ALS. n48 During the same era as the Frank decision, major developments were taking place in Washington that would ultimately lead to the establishment of standards under section 482 of the Code (as section 45 of the Code had now been renumbered). The early 1960's were marked by a rise in concern on the part of the Treasury that domestic corporations were achieving deferral through transfer pricing practices with tax haven affiliates, and that foreign corporations were avoiding taxes altogether by artificially lowering the profits of their U.S. affiliates. The Treasury contended that section 482 of the Code was not effectively protecting the U.S. tax jurisdiction. $\mathrm{n} 49$ 
Congress responded with legislation intended to stop these perceived abuses. Section 6 of H.R. 10650, as introduced by the House Committee on Ways and Means, provided for a new Code section, section 482(b). n50 Under the House proposal, in section 482 cases involving international transfers of tangibles, unless the taxpayer could demonstrate an arm's length price (defined, in accordance with the traditional view, as a price based on a matching or comparable adjustable transaction), or unless the taxpayer and the IRS could agree on a different method, the transfer price would be determined under a formula based on assets, compensation, and expenses related to the transferred tangible property. n51

The House Report explained the intent of section 6 of the bill as follows:

Present law in section 482 authorizes the Secretary of the Treasury to allocate income between related organizations where he determines this allocation is necessary "in order to prevent evasion of taxes or clearly to reflect the income of any such organizations." This provision appears to give the Secretary the necessary authority to allocate income between a domestic parent and its foreign subsidiary. However, in practice the difficulties in determining a fair price under the provision severely limit the usefulness of this power especially where there are thousands of different transactions engaged in between a domestic company and its foreign subsidiary.

Because of the difficulty in using the present section 482, your committee has added a subsection to this provision authorizing the Secretary of the Treasury or his delegate to allocate income in the case of sales or purchases between a U.S. corporation and its controlled foreign subsidiary on the basis of the proportion of the assets, compensation of the officers and employees, and advertising, selling and promotion expenses attributable to the United States and attributable to the foreign country or countries involved. This will enable the Secretary to make an allocation of the taxable income of the group involved (to the extent it is attributable to the sales in question) whereas in the past under the existing section 482 he has attempted only to determine the fair market sales price of the goods in question and build up from this to the taxable income -- a process much more difficult and requiring more detailed computations than the allocation rule permitted by this bill.

The bill provides, however, that the allocation referred to will not be used where a fair market price for the product can be determined. It also provides that other factors besides those named can be taken into account. In addition, it provides that entirely different allocation rules may be used where this can be worked out to mutual agreement of the Treasury Department and the taxpayer. n52

Predictably, the taxpayer community responded by lobbying Congress to remove section 6 from H.R. 10650, claiming that the regulatory authority under section 482 of the Code was sufficient to curb abuses. n53 Their efforts were rewarded in the Senate version of the bill, which omitted the section. In conference, the House receded. The Conference Report states the reasons as follows:

The conferees on the part of both the House and the Senate believe that the objectives of section 6 of the bill as passed by the House can be accomplished by amendment of the regulations under present section 482 . Section 482 already contains broad authority to the Secretary of the Treasury or his delegate to allocate income and deductions. It is believed that the Treasury should explore the possibility of developing and promulgating regulations under this authority which would provide additional guidelines and formulas for the allocation of income and deductions in cases involving foreign income. n54

Treasury took three years to respond to this invitation. n55 In the meantime, however, significant new developments were taking place in the courts. Oil Base, Inc. v. Commissioner n56 represented a classic case of the application of the ALS to sales commissions paid by a U.S. corporation to its Venezuelan marketing affiliate. These commissions were about twice the amount that the same corporation had paid its previous unaffiliated distributor of the same product in Venezuela, and were twice the amount it was currently paying to distributors in other countries. The taxpayer, however, argued that the Frank standard should be applied instead of arm's length, and that since it still retained higher profits from export sales to Venezuela even after the double commission than from domestic sales, the commissions were "reasonable" under Frank. The Tax Court, in a memorandum decision, disagreed. It held that: It is unnecessary for us to decide whether the sole standard in cases under section 482 is one of an amount which would be arrived at in arm's 
length transactions between unrelated parties. The commissioner has been given much latitude in his use of section 482 when necessary to prevent the evasion of Federal income tax by shifting of profits between taxpayers subject to common control. The burden is on petitioner to show error in respondent's allocation. . There is no evidence to show that the percentage return retained by petitioner on domestic sales would represent a reasonable return on export sales. There is likewise no evidence to show that the amount of commissions and discounts paid to Oil Base, Venezuela, represented a reasonable amount, a fair amount, or an amount which would meet any of the other criteria referred to by the Court in Frank. Certainly the fact that these commissions are almost double those paid by petitioner to unrelated persons in arm's length transactions is evidence that they were not fair and reasonable. n57

Presumably, the taxpayer in Oil Base was encouraged to litigate, despite the egregious facts, because appeal lay to the Ninth Circuit. On appeal, the taxpayer, citing Frank, repeated the argument that the Commissioner erred in applying a standard of arm's length bargaining that was not in the statute. The court of appeals, however, held that the application of arm's length was appropriate:

We cannot agree. Where, as here, the extent of the income in question is largely determined by the terms of business transactions entered into between two controlled corporations it is not unreasonable to construe "true" taxable income as that which would have resulted if the transactions had taken place upon such terms as would have applied had the dealings been at arm's length between unrelated parties.

Frank v. International Canadian Corporation [308 F.2d. 520 (9th Cir. 1962)], did not hold that the arm's length standard established by regulation was improper. It held that it was not "the sole criterion" for determining the true net income of each controlled taxpayer. However, permissible departure from the regulation's arm's length standard was, under the facts of that case, very narrowly limited and the holding has no application to the facts before us.

We conclude that the arm's length bargaining standard was properly applied pursuant to regulation. Hall v. Comm'r, 294 F.2d 82 (5th Cir. 1961). n58

In a footnote, the Ninth Circuit specified that Frank only applied in cases where (a) there was no evidence of an arm's length price, and (b) because of the "complexity of the circumstances . . . it would have been difficult for the court to hypothesize an arm's length transaction." n59

It is difficult to reconcile this reading of Frank with the list of possible standards given by the Frank panel four years earlier, which relegated the ALS to a very minor role. In effect, the Ninth Circuit overruled Frank, holding that the ALS must be applied not only when comparables exist, but also when they do not exist, as the court can "hypothesize" a comparable. This abrupt reversal was very likely influenced by the egregious facts of Oil Base and by the difficulties in applying a "reasonableness" standard. It also seems likely that the Tax Court and the Ninth Circuit were influenced by the perception of widespread abuse as a result of the Washington hearings on the Revenue Act of 1962, and by the endorsement of the Commissioner's powers in the legislative history of that Act. n60

The Commissioner's victory in Oil Base was followed by a series of cases which applied the ALS, although not always to the Commissioner's satisfaction. In Johnson Bronze Company v. Commissioner, n61 the taxpayer formed an international marketing subsidiary in Panama for the majority of its foreign sales accounts. The Commissioner reallocated $100 \%$ of the subsidiary's income to the parent under section 482 of the Code. The Tax Court held that the $100 \%$ allocation was arbitrary and unreasonable. n62 In determining the proper allocation, the court held that "the standard to be applied in every case is that of an uncontrolled taxpayer dealing at arm's length with another uncontrolled taxpayer." n63 In a footnote, the court referred to Frank as requiring a choice between the "reasonable" and "arm's length" standards, but stated that "on this subject we shall only say that, on the facts of this case, the only reasonable price charged by petitioner would be one which would have been arrived at if the parties were at arm's length." n64 The court then held that the allocation should be based on the prices charged by unrelated parties that bought the same products from the taxpayer for resale in foreign markets. n65 
Eli Lilly \& Company v. Commissioner, n66 the first of several section 482 cases involving pharmaceutical manufacturers, involved transfer pricing between Eli Lilly and Company (Lilly) and its subsidiary which qualified as a WHTC. The Commissioner based his reallocation on the profit earned by Lilly on sales to domestic distributors, arbitrarily divided in half to reflect volume discount. The Claims Court agreed, holding that Lilly's contention that it should be allowed to benefit from the tax subsidy to Western Hemisphere trade corporations "would require the court to ignore the provisions of Treas. Reg. 1.482-1," requiring the application of the ALS. This is because if the subsidiary were unrelated it would not have been able to retain all the profit on the sales. n67

Lilly then cited Frank, in arguing that its allocation was motivated by business purposes and was "fair" and "reasonable," and thus that the ALS should not control. The Court of Claims disagreed:

The Ninth Circuit has since indicated that only a very narrow departure from the arm's length standard was allowed in the particular circumstances of Frank [citing Oil Base]. Moreover, even accepting Eli Lilly's interpretation that Frank establishes a criterion of a fair and reasonable price, such a price can best be determined by hypothesizing to an arm's length transaction. The thrust of section 482 is to put controlled taxpayers on a parity with uncontrolled taxpayers. Consequently, any measure such as "fair and reasonable" or "fair and fairly arrived at" must be defined within the framework of "reasonable" or "fair" as among unrelated taxpayers. Simply because a price might be considered "reasonable" or "fair" as a business incentive in transactions among controlled corporations, does not mean that unrelated taxpayers would so consider it. Thus, even if the arm's-length standard is not the sole criterion, it is certainly the most significant yardstick. n68

The problem, as the taxpayer pointed out, is that in the absence of any comparables, it is unclear how the arm's length price should be "hypothesized." To this question, the Court of Claims gave no answer. It rejected the comparables offered by Lilly (bulk sales to government agencies) because the market was not comparable, yet accepted the revenue agent's arbitrary decision to cut the profits of the Western Hemisphere trade affiliates by half because the results were "reasonable." n69 When examining the outcome, it is hard to see what relevance the ALS had to the court's ultimate determination. n70

In 1968, the regulations under section 482 of the Code were finalized, and thereafter, they formed the starting point of the analysis in the courts. n71 With few changes, these regulations applied to transfer pricing until the temporary regulations became effective in April, 1993. n72 Despite the invitation in the legislative history of the 1962 act, the Treasury made no attempt to devise "formulas" to apply section 482 of the Code. n73 Instead, for the first time, the regulations attempted to establish rules for applying the ALS to specific types of transactions, but with different degrees of specificity. n74 For services, the regulations merely recited the ALS without any guidance as to its application in the absence of comparables. n75 For intangibles, the regulations contemplated a failure to find comparables. They list twelve factors to be taken into account, but without establishing any priority or relative weight among them. n76

The greatest detail was given for transfers of tangible property. Treasury Regulation section 1.482-2(e) described the three methods that should be used in determining an arm's length price: the comparable uncontrolled price ("CUP") method, the resale price method, and the cost plus method, in that order of priority. n77 All

three methods relied on finding comparable transactions, either directly or by reference to appropriate markups. n78 In the absence of comparables, the regulations stated that:

Where none of the three methods of pricing ... can reasonably be applied under the facts and circumstances as they exist in a particular case, some appropriate method of pricing other than those described in subdivision (ii) of this subparagraph, or variations on such methods, can be used. n79

The courts were, therefore, left free to determine their own "fourth methods" in the absence of comparables.

These regulations effectively ensured that the courts would apply the ALS. A 1970 case, Woodward Governor Company v. Commissioner, n80 may have represented the last challenge to the standard. The taxpayer organized foreign subsidiaries to act as marketing agents for overseas sales of aircraft parts. The Commissioner applied the resale 
price method in reallocating income to the taxpayer. The taxpayer argued that the regulations were invalid in their requirement that the ALS should govern all cases. In the alternative, they argued that if the ALS should be applied, the CUP method should be used on the basis of sales of the same parts to General Electric. The Tax Court accepted the latter argument and therefore did not reach the former. n81

In the meantime, other courts were finding that the ALS must be applied in section 482 cases. Baldwin-LimaHamilton Corp. v. United States n82 involved transfer pricing between the taxpayer and its WHTC subsidiary. The Commissioner reallocated all of the income of the subsidiary to the taxpayer. The district court held that the reallocation was arbitrary, and upheld the taxpayer's allocation based on pricing studies using assumptions that were "tipped in the taxpayer's favor," by using inappropriate comparables. n83 The court of appeals reversed in part, and remanded to the district court for partial re-allocation on the basis of the ALS, stating that the district court "should reject those aspects of the [taxpayer's] theories which do not meet the arm's length standard." n84

United States Gypsum Co. v. United States, n85 involved two section 482 issues: shipping fees paid by the taxpayer to its Panamanian subsidiary and transfer pricing for goods sold by the taxpayer to its WHTC. The district court held for the taxpayer on both issues. On the shipping issue, it held that the amounts were "reasonable and ... equal to an arm's length charge" because they were "within the range" of unrelated party prices (based on comparables). n86 On the transfer pricing issue, the district court held that even though the prices were arbitrarily set to shift income to the WHTC, on the basis of cases like Frank and Polak's Frutal which allowed similar mark ups, the prices were "not unreasonable" (which the district court considered to be automatically equivalent to arm's length). n87

The Court of Appeals for the Seventh Circuit affirmed the first holding and reversed the second. n88 On the shipping issue, the Seventh Circuit had considerable misgivings as to whether the alleged comparables were indeed comparable, and whether unrelated parties would not have adjusted the terms of the contract once the profits that the shipping subsidiary was making became clear, but affirmed under a "clearly erroneous" standard. n89 On the transfer pricing issue, the Seventh Circuit reversed, rejecting the district court's reliance on Frank and its predecessors and its application of a "reasonableness" standard:

We do not consider the cited cases helpful in deciding whether, as a matter of fact, USG's prices to [the WHTC] were the same as would have been reached in arm's length dealing. Insofar as these cases support a proposition that there may be "reasonable" prices, different from those which would have been reached in arm's length dealing, which will result in clearly reflecting the income of controlled taxpayers, we respectfully decline to follow them. n90

Thus, the Seventh Circuit held, as argued by the Commissioner, that applying the ALS was mandatory in all section 482 cases. n91 Two other cases from approximately the same period illustrate the courts' determination to adhere to the ALS even when the Commissioner attempted to apply a different standard. PPG Industries, Inc. v. Commissioner n92 involved the application of section 482 of the Code to a Swiss marketing subsidiary of a U.S. manufacturer of glass, paint, and chemical products. The Tax Court held for the taxpayer on the grounds that (a) the Commissioner's original allocation, based on the Source Book of Statistics of Income, was arbitrary and did not meet the ALS; n93 (b) most of the taxpayer's sales were at arm's length prices based on comparables; n94 and (c) the Commissioner's comparable for the remaining sales was inappropriate, and the taxpayer's allocation was "fair" and "reasonable" and therefore met the arm's-length standard. n95

Ross Glove Co. v. Commissioner n96 represents the application of section 482 of the Code to an inbound transaction, involving the sale of sheepskins to the taxpayer by a Bahamian corporation which also provided sewing services. The Commissioner attempted to hold the taxpayer to its representations to the Philippine authorities, regarding the markup on its costs for currency control purposes. The Tax Court rejected this argument and held that "there is nothing in section 482 or the regulations thereunder to indicate that the arm's-length standard of section 482 is to be ignored simply because of representations made in foreign countries." n97 The court then determined the transfer price on the basis of arbitrary adjustments to an approximate comparable. n98 
Finally, perhaps the greatest triumph for the ALS came in Lufkin Foundry and Machine Co. v. Commissioner. n99 The case involved transfer pricing between the taxpayer and its WHTC. The taxpayer introduced evidence regarding the reasonableness of its marketing arrangements, and the Tax Court held for it on that basis. n100 The Commissioner appealed, citing the need to meet the ALS and arguing that no evidence regarding a taxpayer's internal operations could satisfy the standard on its own. n101 The Fifth Circuit held for the Commissioner, stating that -

No amount of self-examination of the taxpayer's internal transactions alone could make it possible to know what prices or terms unrelated parties would have charged or demanded. We think it palpable that, if the [arm's length] standard set by these unquestioned regulations is to be met, evidence of transactions between uncontrolled corporations unrelated to Lufkin must be adduced in order to determine what charge would have been negotiated for the performance of such marketing services. n102

The courts came a long way. A mere decade before Lufkin, the Frank court had declared that, contrary to the regulations, the ALS was only one of many possible criteria under section 482. n103 It then became the sole criterion, set by "unquestioned" regulations, and any attempt to establish transfer prices without referring to comparables was invalid. Little guidance, however, was given on what to do in the absence of comparables; and in light of his failed attempts in PPG Industries and Ross Gloves to use evidence that was not based on the ALS, the Commissioner may well have wondered whether his victory in Lufkin could turn out to be a pyrrhic one.

\section{DECLINE}

The period between 1972 (when Lufkin was decided) and 1992 (when the proposed section 482 regulations were issued) can be described as a gradual realization by all parties concerned, but especially Congress and the IRS, that the ALS, firmly established by 1972 as the sole standard under section 482, did not work in a large number of cases, and in other cases its misguided application produced inappropriate results. The result was a deliberate decision to retreat from the standard while still paying lip service to it. This process, which began with the 1986 amendments to section 482, was exacerbated by the White Paper in 1988, and culminated in the proposed section 482 regulations of 1992, the temporary section 482 regulations of 1993, and the final section 482 regulations of 1994, essentially eliminated the traditional ALS for the great majority of section 482 cases.

The decline of arm's length can be illustrated by comparing major international section 482 cases decided prior to 1973, with major cases decided after 1973 and prior to 1993. Relative to the cases of the pre-1973 era, comparables were infrequently found in the later cases. n104 The causes for this decline in the application of arm's length are complex, and are discussed more fully in section V. Part of the explanation, of course, is that after the courts accepted the ALS, cases where comparables could easily be found were less likely to get litigated. But the fact that litigation proliferated nonetheless suggests that in too many cases the ALS was not workable. In order to understand why, it is necessary to examine the major section 482 cases from the last two decades. n105

Consider first some major cases in which a comparable was found. R.T. French Co. v. Commissioner, n106 decided in 1973, illustrates one type of problem that the IRS encountered in applying arm's length. In French, the taxpayer, a U.S. subsidiary of a U.K. parent, negotiated a royalty rate for the parent's valuable patented process for producing instant mashed potatoes in 1946, for a 21 year period. This was before the profitability of the process was known and when there was an unrelated $49 \%$ minority shareholder in the parent. In 1960, when the minority shareholder had been bought out and the process had proved extremely profitable, the licensing contract was amended, but the royalty rate remained unchanged for the duration of the contract. n107

The Service argued that unrelated parties would have amended the royalty rate so that it would be commensurate with the income derived from the patent, and that the low rates of the contract resulted in constructive dividends to the U.K. parent, which should be subject to withholding. n108 The Tax Court disagreed. It held that the original 1946 contract was negotiated at arm's length because of the $49 \%$ minority shareholder in the U.K. parent: "The position of [the 
minority shareholder] in the scheme of things in all likelihood assured the arm's-length character of the transaction." n109 Thereafter, the fact that profitability changed "in no way detracted from the reasonableness of the agreement when it was made," and there was no basis for a section 482 adjustment "so long as the "arm's length' test is met ... There is no reason to believe that an unrelated party in [the parent's] position would have permitted petitioner to avoid its contractual obligations." n110

French illustrates the fallacy of relying entirely on the arm's length nature of the original contract, when the economic results are clearly disproportionate to the parties' expectations when that contract was signed. The Service found itself in the position of having to argue against the ALS it had espoused for so long, citing as its primary authority a case (Nestle) that was decided in the short interval between Frank and Oil Base, when the standard was not established as the main criterion for section 482. Not surprisingly, the Tax Court found this hard to accept after the Service had worked so hard to establish arm's length as the standard in all section 482 cases. n111 It took 13 years and the 1986 Tax Reform Act to reverse the result of French.

U.S. Steel Corp. v. Commissioner, n112 illustrates another type of problem that is recurrent in applying arm's length: the difficulty of comparing intragroup with outside transactions, even when the same product or service is involved. U.S. Steel owned a Liberian subsidiary, Navios, which it used to ship steel from Venezuela to the United States. The prices charged by Navios were set at a level that would make the steel price equal to the price of domestic steel manufactured by U.S. Steel, and the same price was charged by Navios for shipping for unrelated corporations, albeit at much lower quantities. n113 As a result Navios had high profits which were totally exempt from tax. In Tax Court, the Service successfully upheld its reallocation of \$52 million in profits to the taxpayer. n114

The taxpayer appealed and the Court of Appeals for the Second Circuit reversed. The court held:

We are constrained to reverse because, in our view, the Commissioner has failed to make the necessary showings that justify reallocation under the broad language of section $482 \ldots$ The Treasury Regulations provide a guide for interpreting this section's broad delegation of power to the Secretary, and they are binding on the Commissioner ... [citing the ALS] This "arm's length" standard ... is meant to be an objective standard that does not depend on the absence or presence of any intent on the part of the taxpayer to distort his income ... We think it is clear that if a taxpayer can show that the price he paid or was charged for a service is "the amount which was charged or would have been charged for the same or similar services in independent transactions with or between unrelated parties" it has earned the right, under the Regulations, to be free from a section 482 reallocation despite other evidence tending to show that its activities have resulted in a shifting of tax liability among controlled corporations. n115

The court thus concluded that the only issue was the comparability of Navios' transactions with those of unrelated parties. It held that they were comparable, despite the differences in volume and the assurance of continued service as a result of the parties' relationship, and despite the taxpayer's ability to manipulate the prices of the steel so as to leave a larger profit to the tax exempt shipper. n116 The court stated that:

Attractive as this argument is in the abstract, it is a distortion of the kind of inquiry the Regulations direct us to undertake. The Regulations make it clear that if the taxpayer can show that the amount it paid was equal to "the amount which was charged ... for the same or similar services in independent transactions" he can defeat the Commissioner's effort to invoke section 482 against him. n117

The court rejected the Commissioner's argument that transactions with "independent" parties are only relevant in a competitive market and not where U.S. Steel had a de facto monopoly, holding that this would impose an "unfair" burden on the taxpayer. Finally, it addressed the Tax Court's attempt to return to a reasonableness standard: 
In at least one portion on Judge Quealy's opinion, however, it appears that the reason he relied upon to hold Navios' charges too high is not at all a matter involving the comparison of rates Steel paid to those paid by other steel companies. He said that what the rates paid by Steel must be measured against in order to see if a section 482 reallocation is justified is "what might be a reasonable charge for a continuing relationship involving the transportation of more than 10 million tons of iron ore per year." If this is indeed the inquiry, then the fact that other steel companies paid Navios the same rates Steel did is irrelevant ... We are constrained to reject this argument. Although certain factors make the operations undertaken by Navios for Steel unique -- at one point, for example, Navios' ore carriers were the largest of their kind in the world -- the approach taken by the Tax Court would lead to a highly undesirable uncertainty if accepted. In very few industries are transactions truly comparable in the strict sense used by Judge Quealy ... To say that Pittsburgh Steel was buying a service from Navios with one set of expectations about duration and risk, and Steel another, may be to recognize economic reality; but it is also to engraft a crippling degree of economic sophistication onto a broadly drawn statute, which -- if "comparable" is taken to mean "identical," as Judge Quealy would read it -- would allow the taxpayer no safe harbor from the Commissioner's virtually unrestricted discretion to reallocate. $\mathrm{n} 118$

Given the history of the ALS, it is hard to see how the court could have reached a different conclusion; the "reasonableness" standard used by the Tax Court had, by 1980, been officially pronounced dead for 16 years. n119 However, the Service's frustration at being thus hoist by its own petard is understandable, as is its subsequent attempt to reverse U.S. Steel in regulations. n120 The continued vitality and extensive effect of both French and U.S. Steel was illustrated in one of the major recent section 482 cases, Bausch \& Lomb, Inc. v. Commissioner. n121 In Bausch \& Lomb, the taxpayer licensed its unique process for manufacturing soft contact lenses to an Irish tax haven manufacturer and charged a royalty of five percent. The Irish subsidiary manufactured the lenses for $\$ 1.50$ each and sold them to the taxpayer for $\$ 7.50$ each-- the same price charged by unrelated parties with much higher manufacturing costs for the same product. $\mathrm{n} 122$

The Commissioner's proposed adjustments included eliminating the royalty (on the theory that B\&L Ireland was a contract manufacturer assured of a market for its sales) but adjusting the income to give B\&L Ireland its costs plus a profit of 20\%. n123 The Tax Court held that these adjustments were an abuse of discretion. In a 86-page long opinion it first rejected the Service's "contract manufacturer" analysis on the grounds that there was no contractual obligation by B\&L to purchase the product (as if such an obligation was needed between related parties!). n124 Then, the Tax Court held that the transfer price was correct on the basis of the unrelated sales, despite the economic differences (volume differences, integrated business differences, and the fact that B\&L had much lower production costs than its competitors) between the alleged comparables:

We find that use of the comparable-uncontrolled-price method of determining an arm's-length price is mandatory. The third-party transactions identified by petitioner provide ample evidence that the $\$ 7.50$ per-lens price charged by B\&L Ireland is equal or below prices which would be charged for similar lenses in uncontrolled transactions ... We place particular reliance on the Second Circuit's opinion in U.S. Steel . . . To posit that B\&L, the world's largest marketer of soft contact lenses, would be able to secure a more favorable price from an independent manufacturer who hoped to establish a long-term relationship with a high volume customer may be to recognize economic reality, but to do so would cripple a taxpayer's ability to rely on the comparable uncontrolled price method in establishing transfer pricing by introducing to it a degree of economic sophistication which appears reasonable in theory, but which defies quantification in practice. n125

The court then rejected the argument from disparities of volume and from the taxpayer's lower costs, holding that the \$7.50 price was "a market price" and therefore the taxpayer had "earned the right to be free of adjustment" under U.S. Steel. n126 In the second part of its opinion, the Tax Court applied French and held that the subsequent profitability of the intangible was irrelevant for establishing a royalty rate, even though the licensing agreement in Bausch \& Lomb (unlike the one in French) was terminable at will. n127 Accordingly, the court rejected the taxpayer's 5\% and the Service's $27-33 \%$ rates, and, since there were predictably no comparables, arbitrarily set its own rate at $20 \%$ n n128 
The Commissioner appealed and the Second Circuit affirmed. n129 It admitted that "the Commissioner's position is not without force," but held that under the regulations and the ALS, applying the comparable uncontrolled price method was mandatory, even though economic reality may differ:

The position urged by the Commissioner would preclude comparability precisely because the relationship between B\&L and B\&L Ireland was different from that between independent buyers and sellers operating at arm's length. This, however, will always be the case when transactions between commonly controlled entities are compared to transactions between independent entities. n130

The IRS position would, in effect, "nullify" the CUP method. The court thus felt compelled to affirm that, under the regulations, as long as the ALS governed, uneconomic results would have to be upheld even though transactions between related parties cannot realistically be compared to arm's length transactions. But if that is the case, why should the ALS apply? n131

French, U.S. Steel and Bausch \& Lomb illustrate a major problem in applying the ALS: if inexact comparables are used because the market had changed, n132 or because the relationship between the parties makes for a different nature of transaction, n133 the ALS leads to results that are completely unrealistic as an economic matter. n134 Why, then, were the courts in these cases so avid to find that comparables were controlling? The regulations and precedents applying the ALS provide only partial answers. The main reason was the courts' stated awareness of the morass they would be getting into by seeking to determine transfer prices in the absence of comparables. Decisions (not based on comparables) that cover hundreds of pages only to reach unpredictable and arbitrary results seem to justify this conclusion.

Cadillac Textiles v. Commissioner n135 is an early example of the courts' predicament in a domestic section 482 case. The case involved commissions paid by the taxpayer to a related entity for weaving. The taxpayer relied on the comparability of these commissions to those paid to unrelated entities. n136 The Tax Court, in a memorandum opinion, held that the alleged comparables were dissimilar because of volume differences and because there was no commitment for a continuing relationship -- precisely the same factors that should have been applied in U.S. Steel and Bausch \& Lomb. n137 However, having properly struck down the comparables, and having rejected the Commissioner's allocation as "heavy handed," the court was faced with the necessity of making an arbitrary determination of the transfer price:

Where some allocation is justified, if the respondent fails to follow a reasonable method in making such allocation, the Court must substitute its judgment ... Unfortunately, this places upon the Court the burden of decision without having all the facts ... Looking to the combined profits of both enterprises, and applying [a value added] factor, it is the Court's conclusion that there should be allocated to the petitioner under section $482 \ldots$ the sum of $\$ 100,000$ [instead of $\$ 193,045.37$, as proposed by the Commissioner]. n138

The Tax Court thus applied a "profit split," the method later advocated by the White Paper n139 and ultimately specified in the current regulations. n140 However, as the round figures indicate, n141 the result was largely arbitrary. In the absence of any guidance in the regulations, the court had little choice. This explains why other courts were so reluctant to abandon any comparable, if one could be found. n142

The first major international section 482 case from this period, E.I. DuPont de Nemours \& Co. v. Commissioner, n143 was a major victory for the Service. The facts in Du Pont were particularly favorable to the Service, since the taxpayer admitted that it had set transfer prices with its tax haven (Swiss) marketing subsidiary, DISA, with no reference to anything but maximizing DISA's profitability. An internal Du Pont memo discovered by the Service read: 
"It would seem to be desirable to bill the tax haven subsidiary at less than an "arm's length' price because: (1) the pricing might not be challenged by the revenue agent; (2) if the pricing is challenged, we might sustain such transfer prices (3) if we cannot sustain the prices used, a transfer price will be negotiated which should not be more than an "arm's length" price and might well be less; thus we would be no worse off than we would have been had we billed at the higher price." n144

In the face of these facts, the taxpayer attempted to show that DISA met the resale price method of the regulation. The Court easily rejected this argument:

We have itemized the special status of DISA -- as a subsidiary intended and operated to accumulate profits without much regard to the functions it performed or their real worth -- not as direct proof, in itself, supporting the Commissioner's reallocation of profits under Section 482, but instead as suggesting the basic reason why plaintiff's sales to DISA were unique and without any direct comparable in the real world ... the vital prerequisite for applying the resale price method is the existence of substantially comparable uncontrolled resellers ... there is nothing in the record showing the degree of similarity called for by the regulation. n145

The Court, having rejected the taxpayer's comparables (drawn largely from general industry averages and the IRS Sourcebook of Statistics of Income), was faced with the necessity of either determining its own transfer price, or accepting the Service's allocation. Unlike the court in Cadillac Textiles, this Court decided to take the easier route and accept the Service's position:

The amount of reallocation would not be easy for us to calculate if we were called upon to do it ourselves, but Section 482 gives that power to the Commissioner and we are content that his amount (totalling some \$18 million) was within the zone of reasonableness. n146

In determining reasonableness, the court relied on ratios of gross income to total operating costs for functionally similar corporations, and on rates of return for 1,100 corporations in general, n147 thus prefiguring the methods of the recently issued proposed, temporary and final regulations. n148 However, there was no suggestion that this reallocation constituted an application of the ALS. The opinion drew a spirited concurrence from Judge Nichols, who pointed out some of the problems with the court's approach:

The evidence referred to supports [the result] in the weakest possible way ... [we are] making bricks without straw . . . Assuming, still, that no formula prescribed by regulation can be used, if the Commissioner adheres in court to his original method, it would seem we would have to affirm him unless we thought his choice of method arbitrary and capricious ... It is not surprising, therefore, that taxpayer's able counsel here put all his chips on the regulatory resale price method, to the virtual exclusion of any reliance on any "fourth method," really a chaos of any and all methods ... Whether the involved regulations leave too many cases for the fourth method is a question the court touches on lightly. The congressional request to write regulations to govern these section 482 reallocations is one sentence long: [']It is believed that the Treasury should explore the possibility of developing and promulgating regulations under this authority [section 482] which would provide additional guidelines and formulas for the allocation of income and deductions in cases involving foreign income[']. Clearly the result of our decision is that this has not been done in respect to the reallocation here involved, and it remains in the almost if not wholly unreviewable discretion of the 
Treasury, as it was when the suggestion was made ... [The Treasury] should not have discretion to decide how much money anyone should have to pay to support the government. n149

Du Pont was the last major international section 482 decision in which the Service was the clear victor. The 1980's, starting with the Second Circuit's reversal in U.S. Steel, saw a series of section 482 related disasters for the IRS. In 1983, for instance, the Tax Court decided Hospital Corporation of America v. Commissioner. n150 Here, the taxpayer formed a Cayman Islands subsidiary to perform a contract to manage a hospital in Saudi Arabia. The subsidiary ("LTD") performed "minimal" functions, and all the substantial work on the contract was done by the taxpayer. The Commissioner argued that LTD was a sham, or alternatively, that all of its income should be allocated to the taxpayer. n151 The Tax Court, in an 82 page opinion, rejected both arguments. It held that LTD was not a sham because it "actually carried on some minimal amount of business activity" and had officers and directors who negotiated the contract, even though the same persons were also officers and directors of the taxpayer. n152 On the section 482 issue, the Court held that the Commissioner abused his discretion by the $100 \%$ allocation, because this represented a repetition of the "sham" argument. n153 Since there were no comparables suggested by any side, the Court was forced to make an arbitrary profit split determination:

Even though we have rejected respondent's 100-percent allocation of taxable income from LTD to petitioner, the evidence indicates overwhelmingly that an allocation is necessary and proper in this case. . . . Unfortunately, there is little quantitative evidence in this record upon which we can determine what a reasonable allocation of profits would be. Neither party has been particularly helpful to the Court in this regard. However, we must do the best with what we have. ... Using our best judgment on the lengthy and inconclusive record before us, we have concluded and found as a fact that 75 percent of the taxable income of LTD in 1973 was attributable to petitioner. n154

While a $75 \%$ allocation may seem favorable to the Service, on the facts of the case, a $100 \%$ allocation would have been justified, since LTD, in effect, performed no economic functions whatsoever. Not surprisingly, the proposed regulations attempted to reverse the result in this case. n155 The next debacle for the Service was Eli Lilly \& Co. v. Commissioner, n156 which resulted in a particularly length Tax Court opinion of 196 pages. Lilly was one of a series of cases concerning transfers, by pharmaceutical giants, of valuable patents developed as a result of extensive domestic research and development in the U.S.. Thereafter, the patents were transferred on a tax-free basis to Puerto Rican subsidiaries who could reap their rewards and benefit from Puerto Rico's tax haven status. As an economic matter, there was no justification of letting the Puerto Rican subsidiary reap the rewards of the research done by the taxpayer without paying any royalty or other consideration for the patents. n157

The taxpayer organized the subsidiary, Lilly P.R., in 1965, after having developed certain extremely lucrative patented processes. It transferred the patents to Lilly P.R., which relied on the patents to become the sole manufacturer of two drugs, Darvon and Darvon-N. Lilly P.R. then sold these drugs to the taxpayer, who in turn marketed the products throughout the U.S.. n158 The Commissioner reallocated the entire income from the patents to the taxpayer, arguing that Lilly P.R. was a mere contract manufacturer and that its ownership of the intangibles should be disregarded. The Tax Court rejected this approach, holding that the legal ownership of the intangibles could not be disregarded. n159 It also rejected the Commissioner's argument that the separation of income from expenses to create the patents led to a distortion, mainly because the expenses were incurred largely in the 1950's, long before the transfer, and had been recovered previously. n160

The Tax Court then reached the issue of proper transfer pricing under the ALS. The prices paid by the taxpayer were such that it could not use the profits to fund its current R\&D. The Tax Court held that this was unacceptable: "It is inconceivable that petitioner, negotiating at arm's length, would have transferred valuable income-producing intangibles without a royalty, lump-sum payment, or other agreement that would enable petitioner to continue its general research and development activities." n161 Thus, some section 482 allocation was necessary. However, as the drugs had been patented for two of the years in question, there were no com- [*125] parables. Hence, the three regular methods (CUP, cost plus, and resale price) were inapplicable. Having rejected both parties' expert witnesses, the Court was obliged to 
determine an arbitrary "reasonable profit split" based on the functions performed by the parties. Under the profit split, the Court allocated to Lilly P.R. 100\% of manufacturing costs plus location savings, and 55\% of its income from marketing intangibles. n162 The result was a reallocation to the taxpayer of \$23-24 million for the 1971-72 tax years, instead of $\$ 53$ million as advocated by the Commissioner. n163

Both parties appealed. The Court of Appeals for the Seventh Circuit reached a result which was even more favorable to the taxpayer. n164 It rejected the Tax Court's argument that Lilly would not have transferred the patents to an unrelated party without getting enough consideration to fund its ongoing R\&D, holding that the stock of Lilly P.R. received by the taxpayer, together with distribution rights and technical assistance contracts, constituted sufficient consideration. n165 The Court of Appeals, nevertheless, approved the profit split method as "not unreasonable," but remanded for an adjustment that did not require Lilly P.R. to participate in the taxpayer's R\&D expenses. n166 It took the 1986 amendments to section 482 to reach a more economically reasonable result. n167

The Service fared even worse in G.D. Searle \& Co. v. Commissioner, n168 the companion case to Lilly. Like Lilly, Searle transferred drug patents to its Puerto Rican subsidiary (SCO) for no consideration; however, SCO subsequently manufactured and sold the drugs to unrelated parties so no transfer price issue was involved. The Tax Court rejected the Service's attempt to ignore the transfer of the intangibles and allocate the income to the taxpayer by treating SCO as a contract manufacturer. n169 The court then held that some consideration for the transfer was necessary as the intangibles accounted for $80 \%$ of the taxpayer's income and transferring the patents to an unrelated party solely for stock would be "the height of corporate mismanagement." n170 As there were no comparables, the Tax Court was required to use its arbitrary "best judgment" and allocated to the taxpayer \$29 and \$34 million for the two years in question (25\% of SCO's total net sales), compared to the $\$ 92$ and $\$ 110$ million sought by the Service. n171 Significantly, the court did not attempt to characterize this result as the product of an arm's length allocation; instead, the court reasoned "arm'slength consideration for section 482 purposes is that which results in a clear reflection of income." n172 This remarkable tautology (the standard for clear reflection is arm's length, and arm's length is whatever results in clear reflection) marks a low point in the courts' attempts to apply the ALS in the absence of arm's length transactions.

The Service fared equally badly in its attempts to avoid the results of its own regulations in Ciba-Geigy Corp. v. Commissioner, $\mathrm{n} 173$ an inbound section 482 case. The case involved the appropriate rate of royalty to be paid by the taxpayer to its Swiss parent under an exclusive license in which all the significant R\&D had been done at the parent level. The Service argued the taxpayer was engaged in a joint venture with the parent and should have paid a lower royalty than $10 \%$ or, alternatively, the arm's length rate was lower. The taxpayer argued for a higher royalty than $10 \%$. The Tax Court rejected the Service's attempts "to deflect the thrust of his own 'transfer or use of intangible property' regulations ... which to respondent's discomfiture fit this case like a glove." n174 Having rejected both parties' proposed comparables (because of different degrees of risk and the uniqueness of the relationship), the court held that the $10 \%$ rate was reasonable, based on the "substantial negotiations" between the related parties n175 and the testimony of an unrelated party who would have paid between $10 \%$ and $12.5 \%$ for a nonexclusive license. n176 The Service's position in this case seems unreasonable, and a higher royalty rate should have been allowed, based on the unexpected profitability of the patent, the difference between exclusive and nonexclusive licenses, and the fact the parent performed the R\&D.

The same arbitrariness and disregard for economic reality persists in two other recent section 482 cases which were decided, like Bausch \& Lomb, after the publication of the White Paper: Sundstrand Corp. v. Commissioner n177 and Merck \& Co. v. United States. n178 Sundstrand involved the license of valuable manufacturing technology for aircraft spare parts to the taxpayer's Singapore subsidiary which in turn sold the parts to the taxpayer for distribution. The Service again attempted to apply its contract manufacturer analysis which seems appropriate because the subsidiary did not develop the product and was guaranteed, although not formally, to sell its products to the taxpayer (the airlines actually refused to buy from the subsidiary directly). The Tax Court, relying on Bausch \& Lomb, rejected this analysis and also rejected all of the taxpayer's and the Service's proposed comparables. n179 Having criticized the parties for their "contentiousness" and lack of cooperation, n180 the court made its own "best estimate" of the appropriate transfer price, relying on the discounts given by the taxpayer on other products and on its representations to U.S. Customs. n181 These bases seem both arbitrary and unrelated to the issue facing the court. With respect to the royalty, the court again rejected all comparables and arbitrarily fixed a rate of $10 \%$. n182 
Merck \& Co. v. United States, n183 a case similar to G.D. Searle, is yet another recent section 482 defeat for the Service. In Merck, the taxpayer developed drugs and transferred the patents to its Puerto Rican subsidiary, MSDQ, which manufactured and sold the drugs to unrelated parties. The Service argued MSDQ should have paid the taxpayer a royalty for its R\&D and marketing assistance. The Claims Court rejected the Service's position in its entirety, and ordered a refund to the taxpayer of \$5 million, plus interest. n184 The court recognized the location of the patents within the group had no business consequences, n185 but held the transfer of the intangibles valid. n186 The court found no continued royalty was required since the costs of R\&D had been recovered before the transfer. n187 The court further found that the taxpayer did not provide any marketing services to MSDQ, despite the overlap of officers and directors and the functional integration between the two companies. n188 The court recognized, as an economic matter, that its decision was untenable, but felt obliged to make it in view of the "all or nothing" positions of the parties.

For tax years 1972 through 1976, MSDQ reported taxable income that totals $\$ 181,802,000$. Federal income tax paid was $\$ 657,000$. The pricing process that produces such disparity between costs of production and end-product prices, and permits the accumulation of retained earnings that amount to 98.82 percent of all reported taxable income, may be economically unjustified or socially unacceptable. Such results may underscore infirmities in the controls to be expected in regulated pharmaceutical markets. Such results do not establish a distortion of income as to MSDQ. Such problems cannot be addressed through Section 482, under the statute and regulations as presently written. n189

Thus, the court ignored the analysis in G.D. Searle, that no party would transfer the intangibles to an unrelated party without consideration. n190 Although this seems facially unjustifiable, any attempt to find the proper royalty rate (if required, since there could be no comparables) in the absence of "some formula or method" n191 must have appeared equally frustrating to the court. What makes Merck remarkable is that arm's length analysis did not enter the court's opinion at all. The only issue discussed was whether Merck performed R\&D and marketing functions for MSDQ, not whether it would have transferred the patents to an unrelated party. By ignoring arm's length, the Claims Court in effect held the standard is inapplicable to an integrated multinational enterprise like Merck, which can shift its intangibles around as it wishes. n192

Merck and Bausch \& Lomb thus mark the end of a process in which the ALS became increasingly irrelevant to section 482 cases. The result demonstrated that the then governing statute and regulations required changing to reflect the economic reality of multinationals. Since 1982, this task has been undertaken by Congress and the Service in the recent proposed, temporary and final regulations, leading to the abandonment of the traditional and narrow ALS for the vast majority of section 482 cases.

\section{FALL}

In 1982, Congress began closing some of the loopholes that were evident in the section 482 cases. The Tax Equity and Fiscal Responsibility Act (TEFRA) altered the treatment of income attributable to intangible assets owned or leased by possessions corporations benefitting from section 936 of the Code. TEFRA amended section 936 to provide that such income would be treated as income of the corporation's U.S. shareholders unless the corporation elected to make cost sharing payments to its parent or to split the profit from products produced in the possession of the parent on an equal basis. n193 In passing TEFRA, Congress sought to redress the distortion of income resulting from the separation of R\&D activity and the income derived from the intangible. n194 Thus, the specific Puerto Rican affiliate problem of Lilly, G.D. Searle and Merck was addressed, but only for post-1982 transfers with no inference regarding prior law.

The next step was taken in the Deficit Reduction Act of 1984, which amended section 367(d) to treat a tax-free transfer of intangibles to related foreign corporations as a sale of the intangible for annual payments over the useful life of the property contingent on its productivity, use, or disposition. n195 However, no inference was intended for licenses of intangibles, which continued to be governed by section 482. By 1985, Congress realized U.S. Steel and Lilly indicated something should be done about the general application of section 482 of the Code, beyond the specific issues 
of Puerto Rican corporations or transfers to foreign affiliates. The House Report on House Bill 3838 states the problem as follows:

Many observers have questioned the effectiveness of the "arm's length" approach of the regulations under section 482. A recurrent problem is the absence of comparable arm's length transactions between unrelated parties, and the inconsistent results of attempting to impose an arm's length concept in the absence of comparables. ...

A fundamental problem is the fact that the relationship between related parties is different from that of unrelated parties. Observers have noted that multinational companies operate as an economic unit, and not "as if" they were unrelated to their foreign subsidiaries. In addition, a parent corporation that transfers potentially valuable property to its subsidiary is not faced with the same risks as if it were dealing with an unrelated party. Its equity interest assures it of the ability ultimately to obtain the benefit of future anticipated or unanticipated profits, without regard to the price it sets. The relationship similarly would enable the parent to adjust its arrangement each year, if it wished to do so, to take account of major variations in the revenue produced by a transferred item. ...

Certain judicial interpretations of section 482 suggest that pricing arrangements between unrelated parties for items of the same apparent general category as those involved in the related party transfer may in some circumstances be considered a "safe harbor" for related party pricing arrangements, even though there are significant differences in the volume and risks involved, or in other factors. See, e.g., United States Steel ... While the committee is concerned that such decisions may unduly emphasize the concept of comparables even in situations involving highly standardized commodities or services, it believes that such an approach is sufficiently troublesome where transfers of intangibles are concerned that a statutory modification to the intercompany pricing rules regarding transfers of intangibles is necessary. n196

The specific solution proposed by the House bill, however, was relatively narrow. It would have added the following sentence to section 482: "in the case of any transfer (or license) of intangible property (within the meaning of section 936(h)(3)(B)), the income with respect to such transfer or license shall be commensurate with the income attributable to the intangible." n197 Other than rejecting the approaches of French and U.S. Steel, no attempt to modify section 482 more extensively along the lines suggested in the House Report was forthcoming.

Nevertheless, it is noticeable that the House did not pretend that the "commensurate with income" standard was compatible with the ALS. The report states the transferor of intangibles in a multinational was looking to its equity investment, "rather than to 'arm's length' factors," to recuperate its cost n198 and that "industry norms or other unrelated party transactions do not provide a safeharbor minimum payment for related party intangible transfers." n199 Thus, even if a perfect comparable could be found in which the same intangible was transferred to an unrelated party in the same circumstances for a fixed royalty rate, the provision would still require the allocation of "super-royalties" to a related party transferor.

The conference agreement on the Tax Reform Act of 1986 followed the House bill except for the expansion of the "commensurate with income" provisions to apply to inbound as well as outbound transfers n200 such as the transfer in Ciba-Geigy. However, the report added the following significant language:

The conferees are also aware that many important and difficult issues under section 482 are left unresolved by this legislation. The conferees believe that a comprehensive study of intercompany pricing rules by the Internal Revenue Service should be conducted and that careful consideration should be given to whether the existing regulations could be modified in any respect. n201 
In light of this language, the report should be seen as an invitation to the Service to shift the focus of the regulations away from the ALS. The result of this invitation was the 1988 White Paper, n202 the 1992 proposed regulations, n203 the 1993 temporary regulations, n204 and the 1994 final regulations under section 482 of the Code. n205

In discussing the White Paper, it is necessary to distinguish between what it does and what it says it does. First, the White Paper does contain an excellent analysis of the evolution of the statute, the regulations, and the case law under section 482 of the Code, n206 as well as an overview of the Service's experience in administering the law and regulations. n207 The analysis suggests that the regulations rely too heavily on finding comparables, n208 that the case law indicates that the regulations "fail to resolve the most significant and potentially abusive fact patterns," n209 and that the "fourth method" developed in the courts has been inadequate. n210

After explaining the 1986 changes, n211 the White Paper reaches the heart of the matter: determining what method should apply to section 482 issues in the absence of comparables. It rejects the applicability of safe harbors because they will only serve as a "floor" for taxpayers unable to obtain better results otherwise. n212 The White Paper instead suggests two methods based on determining appropriate returns from a functional analysis of the parties' respective economic contributions. n213 The first or "basic" method applies when one party does not use significant intangibles of its own. n214 The economic functions of that party are analyzed and appropriate rates of return are identified based on the rates of return of unrelated parties performing similar activities and assuming similar risks. n215 The residual is then assigned to the other party. n216

The second or "profit split" method applies when both parties perform complex economic functions, bear significant economic risks, and use significant self-developed intangibles. n217 After applying the basic method to the measurable assets of both parties, the residual is allocated between them by splitting the profits based on the relative values of each party's intangibles. n218 The White Paper acknowledges that "splitting the intangible income in such cases will largely be a matter of judgment." n219

This is what the White Paper proposes. The Paper, however, also has another agenda: to portray its suggested methods as compatible with the traditional ALS. n220 This agenda developed because of the strong objections by our trading partners to the language contained in the 1986 legislative history advocating the abandonment of the ALS. n221 Thus, as we saw above, the White Paper recommends that the U.S. continue to adhere to the ALS. n222 Furthermore, the methods summarized above (including profit split) were given the name "basic arm's length return method " (BALRM). n223 Finally, the White Paper contains one chapter devoted to demonstrating the compatibility of the "commensurate with income" standard and the BALRM method with the ALS, n224 one chapter defending the ALS on economic grounds, n225 and an appendix attempting to demonstrate that other countries use methods which are similar to BALRM. n226

The White Paper also contains one real concession to the ALS in that it permits taxpayers to avoid periodic adjustments to a royalty rate for intangibles if they can find a comparable lacking such adjustments. n227 This provision flies in the face of the statutory language and the legislative history of the 1986 amendments, n228 but Treasury presumably felt it could not claim to be adhering to the ALS without allowing taxpayers to use comparables if they found them. Indeed, under the White Paper's proposed "clear and convincing evidence" standard, such comparables in practice will be hard to find. n229 Whether the BALRM itself is compatible with the ALS depends upon which definition of the ALS is used. The White Paper relies on the 1979 OECD report on transfer pricing, which permits "some regard to the profits of the relevant [multinational enterprise]" in determining transfer prices in the absence of comparables. n230 However, this language falls far short of endorsing the use of either the profit split method advocated by the White Paper or the industry average rates of return. n231

It is difficult to see in what way the BALRM can meaningfully be called an ALS method in the traditional sense. First, since BALRM by definition can only be applied in the absence of comparables, it falls outside the traditional definition of the ALS, which relies on comparables. Thus, BALRM can only be called an "arm's length method" if the definition of what constitutes "arm's length methods" is expanded to include any method that reaches results that are the same as those that would have been reached by unrelated parties. If this is the definition, then "arm's length" includes the entire transfer pricing continuum, including formulary apportionment, because even pure formulary apportionment may, in appropriate cases, reach the same results as would have been reached by unrelated parties dealing at arm's length. 
Second, even if one assumes arm's length dealings proceed from such a functional analysis as envisaged by the BALRM, such an analysis could never lead the parties to a definite fixed transfer price. As Langbein has argued, it could only lead to a range between the minimum the selling party could expect to get based on its costs and the maximum the buying party would be willing to pay based on its resale price. In most related-party contexts, there will be a residual profit not allocable to any constituent member, but rather to the existence of the overall organization. n232 Thus, unlike a comparable with a fixed price, applying the BALRM between unrelated parties, at best, could lead to a range of acceptable transfer prices. However, the disparity between one end of the range (advocated by the taxpayer) and the other (advocated by the Service) could still be immense. Furthermore, the disparity can only be resolved by applying profit split methods which do not depend on comparables and, hence, fall outside the traditional ALS.

Thus, the true message of the White Paper was that the traditional ALS could not be applied to the majority of section 482 cases because no comparables could be found. What the White Paper instead achieved was to substitute an expanded definition of the ALS for the traditional one: ALS was now understood to include not only CUP, cost plus, and resale price but also the rest of the transfer pricing continuum, up to and including profit split, as long as the results reached were compatible with arm's length results. This expansion of the scope of arm's length was the major achievement of the White Paper and constituted a revolution in the United States' approach to transfer pricing. The full fruits of such revolution can be seen in the 1994 final regulations. n233

The methods that the White Paper suggested as a replacement for the traditional ALS, however, have at least two flaws which have been pointed out repeatedly since 1988. n234 First, BALRM analysis is extremely complicated and requires massive input by economists and accountants, as well as access to a large fund of not easily available information. n235 Second, even where the method is applied correctly, it still leaves a substantial residual to be split in many cases, and the White Paper provided no guidance on the ways to split it. The BALRM was thus unlikely to reduce the amount of section 482 litigation or the length of the ensuing opinions because the economists of the Service and the taxpayer predictably differ. When millions of dollars are involved, as is the case in most major section 482 cases, the matter is likely to end up in court. In fact, functional analysis was included in the IRS manual and applied before 1988, with no discernible lessening of the section 482 litigation mess. n236

By 1992, these drawbacks of BALRM persuaded the Service it could not be applied in practice. As a result, when, in accordance with the 1986 legislative history, the proposed regulations came out in January 1992, they made no attempt to implement the White Paper. The preamble to the proposed regulations states that

Many comments on the White Paper criticized the prominent role given to BALRM, arguing that BALRM would be difficult to apply because the information BALRM required generally would not be available, would be unfair to corporations whose rates of return vary considerably from the average, and would allocate too much income to U.S. entities. The Service also was urged to assign a greater role to inexact comparable transactions and to reconsider the use of safe harbor rules. These comments were taken into account in the development of the three pricing methods described in ... these proposed regulations. n237

Instead of BALRM, the proposed regulations introduced the "comparable profit interval" (CPI) method, n238 which represented another step towards the demise of the traditional ALS as the guiding standard for applying section 482 of the Code.

The proposed regulations were divided into three parts: intangibles, tangibles, and cost sharing. In the case of transfers of intangibles through transfers of tangibles or services, the intangible rules applied if the income attributable to the intangible was "material" in relation to the income attributable to the tangible property or services. n239 In the case of intangibles, when a strictly defined "matching transaction" involving the same intangible under the same or substantially similar economic conditions and contractual terms was lacking, n240 the next method in order of priority was the "comparable adjustable transaction" ("CAT") method. n241 Under the CAT method, the arm's length consideration was determined "by reference to the consideration charged in an uncontrolled transfer involving the same or similar intangible under adjustable economic conditions and contractual terms." n242 To be considered adjustable, 
the contractual terms and economic conditions must be sufficiently similar such that the effect of any material differences can be determined with reasonable accuracy; n243 however, even if all the other conditions for applying the CAT method are met, "an uncontrolled transfer will not meet the standards [of the CAT method] if the consideration determined by reference to that transfer results in a level of operating income for the tested party ... that is outside of the comparable profit interval." n244

In the case of transfers of tangible property, the first method to be applied was the CUP method. n245 Under the CUP method, the consideration for tangible property was determined by considering uncontrolled transfers of the same or similar physical property in the same or similar circumstances if any differences could be reflected by a reasonable number of price adjustments. n246 The CUP method was the only method for tangibles not subject to verification by means of the CPI. n247 When the CUP method was unavailable, other methods such as resale price, cost plus or "fourth method" could be used, but the results from these methods were all subject to testing under the CPI and the ultimate method used was supposed to reach results at the "most appropriate point" within the CPI. n248

The CPI itself was constructed in a series of steps. First, the tested party was selected. n249 Second, the "applicable business classification" of the tested party was determined on the basis of the businesses whose operations most closely corresponded to the tested operations involving related parties. n250 Third, constructive operating incomes were derived by applying profit level indicators from a selection of uncontrolled taxpayers in the applicable business classification to financial data of the tested operations. n251 These profit level indicators included the rate of return on assets, ratio of operating income to sales, and profit splits. Fourth, the CPI was determined on the basis of profit level indicators on the basis of complex statistical techniques. n252 Fifth, the "most appropriate point" in the CPI was determined on the basis of other statistical techniques. n253 Finally, the transfer price was determined so as to produce operating income for the tested party which equaled the constructive operating income corresponding to the most appropriate point in the CPI. n254 In general, the CPI was to be constructed based on actual, rather than projected, results from the three year period beginning with the year prior to the one under review. n255

Is the CPI method of the proposed regulations compatible with the traditional ALS? As our trading partners promptly pointed out, the answer is no, n256 even under the Treasury's own definition of what constitutes an ALS method. n257 This definition of an ALS method was based on the definition offered in a 1979 OECD Report which endorsed the ALS and explicitly rejected formulary approaches for allocating profits between related enterprises as "necessarily arbitrary." n258 It accepted, however, the possibility that "in seeking to arrive at an arm's length price in a range of transactions, some regard to the total profits of the relevant [multinational enterprise] may ... be helpful, as a check on the assessment of the arm's length price." n259

As the White Paper recognized, the OECD Report endorsed methods which consider the profits of the related enterprises in making arm's length determinations. n260 The CPI method, on the other hand, looked exclusively at the profits of other taxpayers to determine the proper allocation within the controlled group. n261 The CPI then judged the results of any method of allocation which, in the case of intangibles, did not meet strict standards of comparability as a "matching transaction," n262 or, in the case of tangibles, was not based on a "comparable uncontrolled price." n263 If the results of any such method did not fall within the CPI, the transfer price was not considered "arm's length." n264 The CPI method thus fell squarely within the definition of a "global" or formulary method under the OECD report, since it disregarded the transaction between the related parties altogether and substituted a transaction based on an analysis of the profits of third parties. n265 While the CPI method did rely on comparables (unlike the BALRM with profit split, which the proposed regulations rejected), the standard of comparison used was so loose that our trading partners refused to consider it an "arm's length" method. n266

The proposed regulations thus marked a further step in the decline and fall of the traditional ALS based on comparables for the majority of section 482 cases. They would have also likely led to increased double taxation in the absence of agreements with our trading partners. This alone would not necessarily have been enough to condemn them. The proposed regulations, however, were also incompatible with the legislative history of the 1986 amendments (on which they relied for authority), which clearly states "industry norms" should not be the basis for determining transfer prices. n267 More importantly, as many commentators have pointed out, the proposed regulations suffered from other flaws as well. First, they were incredibly complex, requiring the application of statistical methods far beyond the understanding of most tax directors of even the largest corporations. This could have forced taxpayers to devote resources to employing economists and statisticians, rather than in more productive ways. Second, the proposed regulations relied on the ability of taxpayers to obtain information regarding the profitability of their competitors, which 
was unobtainable without breaching antitrust laws. n268 Third, these regulations were unlikely to lead to any significant reduction in litigation, given the many subjective decisions involved in their application (e.g., the selection of the tested party) and the many undefined terms (e.g., "material") that they include. Finally, the proposed regulations were totally useless as a planning tool for taxpayers, because in order to construct the CPI, they required a clairvoyant knowledge of actual future results. n269

In light of this uniformly negative reaction, the IRS rapidly realized a different direction had to be taken. n270 The result was the current temporary and final regulations which, on their face, appear to signal a substantial retreat by the IRS and a reaffirmation of the viability of the ALS. These appearances are, however, misleading. Closer examination reveals the temporary and final regulations will probably ensure the CPI (renamed the comparable profits method, or CPM) will be the method applied in the majority of disputed cases by the IRS to judge whether the transfer price should be adjusted while in other cases a profit split method similar to BALRM, which does not rely on comparables at all, will be used. n271

The temporary regulations, like the proposed regulations, began with the required lip service to the ALS, and omitted the modifications to the ALS that attracted criticism in the proposed regulations. n272 However, the temporary regulations also subjected the ALS to a "best method rule," which is retained in the final regulations, and will be an exception that swallows the traditional ALS. The best method rule ("BMR") states that when the taxpayer and the Service disagree about the pricing methods to be used in reaching ALS results, the method to be used is the one that provides the "most accurate determination" of the arm's length result. n273 The factors to be weighed when choosing the method under BMR are the completeness and accuracy of the data, the degree of comparability with uncontrolled transactions, the number, magnitude and accuracy of adjustments, and whether the result agrees with any other method. n274

How will the BMR be applied in practice? The answer was provided in the examples given in the temporary regulations. The first example involves a non-controversial case where the taxpayer is able to provide a comparable CUP method that fits the transaction "with a small number of minor adjustments." n275 In this case, the BMR will allow the CUP method to overcome the resale price method proposed by the IRS. n276 This first example presupposed an exact comparable exists, but, as the cases surveyed above indicate, no such comparable can be found in the vast majority of real life situations involving a dispute between the Service and the taxpayer. In such a case, the second example comes into play. Here, the taxpayer argues for CUP with "several adjustments" which are not major ones while the Service argues for the resale price method. The CPM method, which is equivalent to CPI, reaches results that are consistent with resale price; therefore, the example indicates the similar results achieved by the resale price method and the CPM overcome the taxpayer's comparable. n277

As Fuller and Aud suggest, this example "borders on the 1992 proposed regulations' requirement that the resale price method be tested and pass muster under the CPI." n278 In effect, whenever the IRS and the taxpayer disagree about the pricing method, which is essentially in every case in which the application of the ALS is important, the two competing methods have to be tested under the CPM. Although the temporary regulations refrained from mandating, they strongly suggested that the method that is consistent with the CPM should prevail. Thus, in the temporary regulations, as in the proposed regulations, unless the taxpayer can find an exact comparable or one that requires only minor adjustments, the CPM will be used to "trump" any taxpayer method (including the CUP) that is inconsistent with its results. n279

The conclusion that the temporary regulations represent only a tactical retreat by the IRS from the proposed regulations' emphasis on the CPI is bolstered by examining the precise methods used for tangible and intangible transfers. For tangible property, the temporary regulations permit the use of CUP, resale price, cost plus, CPM, or "other methods." n280 While CUP "ordinarily will provide the most accurate measure of an arm's length price for the transfer of tangible property," n281 the standard of comparability is that the property and the circumstances must be "substantially the same," n282 and a "reasonable number of adjustments" for "minor" differences can be made only "if such differences have a definite and reasonably ascertainable effect on prices or profits." n283 This level of comparability will rarely be found.

The other permitted methods (resale price and cost plus) do not require such a high standard of comparability; n284 but if the taxpayer disagrees with the Service on their application, the disagreement is likely to be resolved by resorting to the CPM. Thus, in practice, the temporary regulations have the same structure as the proposed regulations because 
the CPM still "trumps" the competing method used by the taxpayer in the absence of an exact comparable. n285 This pattern is repeated with even greater clarity in the intangibles portion of the temporary regulations. The only method that can be used other than the CPM is the "comparable uncontrolled transaction" (CUT) method which requires that the comparable intangible be of the same class, relate to the same type of products, processes, or know-how, and have "substantially the same profit potential" as the transfer at issue. n286 The last requirement is likely to prove impossible to meet because almost by definition intangibles licensed to unrelated parties will not have the same profit potential as those retained within the related group. n287 In the absence of such a precise uncontrolled comparable, the taxpayer is practically required to use CPM. n288

CPM itself is essentially the same as CPI in the proposed regulations, but in some ways it deviates even further from the traditional ALS. CPM is applied to the "tested party," measured by profit level indicators derived from uncontrolled taxpayers that engage in "similar business activities." n289 The definition of "similar business activities" is extremely broad. The uncontrolled taxpayers need be only "broadly similar," while "significant product diversity and some functional diversity between the controlled and uncontrolled transactions is acceptable." n290 If this liberal standard is met, CPM will be applied by constructing an "arm's length range" from the operating profits of the "comparables." CPM can be applied even if the "broadly similar" standard is not met; in that case, the "arm's length range" will "ordinarily" consist of the interquartile range from the 25th to the 75th percentile of the constructive operating profits derived from the profit level indicators of the "comparable" parties. n291

The pretense that CPM is somehow consistent with the traditional ALS because it uses some form of comparables is so thin in this case that it is hard to accept it with a straight face. The "arm's length" result under this rule must be constructed by using the profits of other parties that are not even "broadly similar" to the related taxpayers under an extremely liberal standard of similarity. There is no question this use of the CPM is inconsistent with the 1979 OECD report, which, as we have seen, only allows "some regard to the total profits of the relevant [multinational enterprise] . . . as a check on the assessment of the arm's length price." n292 The temporary regulations thus represent a return to the basic White Paper position of paying lip service to the traditional ALS while, in effect, substituting a much broader and more flexible definition of "arm's length" for it. In practice, whenever a disagreement arises between the taxpayer and the IRS and there is no exact comparable, which is the vast majority of the cases in which the application of the ALS is significant, the winning method is the CPM, according to the Service. The CPM hardly attempts to masquerade as an ALS method.

The final regulations, issued in July 1994, are "generally consistent" with the temporary regulations, and follow the same "basic policies." n293 Once again, the emphasis is on arm's length results. A controlled transaction meets the ALS "if the results of the transaction are consistent with the results that would have been realized if uncontrolled taxpayers had engaged in the same transaction under the same circumstances (arm's length result)." n294 The Best Method Rule (BMR), employed in deciding which method the taxpayer and the IRS should follow, states that the method used must be the one which "provides the most reliable measure of an arm's length result." n295 Thus, the redefinition of the ALS has been completed. A need for the use of any comparable no longer exists; if a method reaches the same result as what would have been reached on an arm's length basis without resort to comparables, it is compatible with the ALS and should be applied.

The main difference between the final and temporary regulations is the increased flexibility that the final regulations afford both the taxpayer and the Service. Instead of relying on the superiority of the CPM, the final regulations emphasize the equal status of all the specified methods, leaving the taxpayer and the Service free to argue which provides the best arm's length results under the BMR. As one commentator has noted, this feature of the final regulations provides taxpayers with "flexibility that may approach that allowed under the 1968 regulations." n296 However, this is hardly a great compliment, given the fate of the 1968 regulations in the courts. As the architect of the 1993 temporary regulations has stated, this may well create greater controversy and litigation in the future, without an end in sight. n297 In practice, it still remains likely, in the view of many commentators, that the Service's field agents will employ the CPM as their method of choice, n298 while taxpayers will prefer other methods. The resulting dispute concerning which method really is the best estimate of arm's length results will arrive in the courts once again.

The most significant innovation of the final regulations is the elevation of profit split to a status equal with all other methods of reaching an arm's length result. The two-level analysis described below may be performed in cases where either party owns significant intangibles resulting in a residual profit higher than the profit resulting from the regular functions of the parties. First, the profits resulting from the standard functions performed by the parties are allocated on 
the basis of market comparables; and second, the residual profit is split according to which party bore the costs of developing the intangibles (and not which party formally owns the intangible). n299 It is likely in many of the cases reaching litigation, that the parties will have significant high-profit intangibles; therefore, the profit split method will be the one applied under the BMR. n300 This "residual profit split" method, however, is clearly not within the traditional ALS because it does not rely on comparables in making the crucial determination about splitting the residual. As the Treasury observed in its release accompanying the final regulations,

the United States for many years has been reluctant to permit wide use of profit split methods because they do not refer solely to results of transactions between unrelated parties in determining an arm's length result. To the extent that they do not rely on such results they may be considered to be inconsistent with the arm's length standard. There are, however, cases in which it is impossible to locate adequate data to reliably apply one of the other methods. In such a case a profit split may be the best available method. n301

The adoption of the profit split method in the final regulations marks the culmination of the trend we have observed since 1972: the fall of the traditional comparable-based ALS and its replacement by an expanded definition of "arm's length," which includes any method reaching arm's length results. Once the conceptual step to an expanded arm's length definition is taken, however, no logical barrier exists to accepting any method which leads to arm's length results, including formulary methods. The actions needed to take this further step are the topic of the final part of this Article.

\section{CONCLUSION: AN ALTERNATIVE APPROACH}

The recent cases, culminating in Bausch \& Lomb, Inc. v. Commissioner n302 and Merck \& Co. v. United States, n303 and the proposed, temporary and final regulations are evidence that the traditional ALS is defunct in practice. Unfortunately, the new final regulations are exceedingly complex, and no relief from the current audit and litigation nightmare is in sight. Therefore, the question is now whether the new, expanded definition of arm's length can be used to replace the current approach with a more simple and practical solution to the transfer pricing problem and whether such a solution may gain world-wide acceptance.

To answer this question, it is first necessary to understand why the traditional ALS has failed. To do so, let us reexamine the theoretical criticism of the ALS, as developed by a succession of critics from 1976 onward. n304 On the most fundamental level, the basic criticism of the ALS is that it does not reflect economic reality. As the courts and Congress have stated, multinational corporations do not regard each subsidiary as a separate entity which bargains with other subsidiaries at arm's length. Multinationals are usually integrated entities to which each subsidiary contributes, and the transfer prices among the constituent subsidiaries are fully under the control of the multinational which naturally considers the tax implications in setting such prices. This fact has been recognized by the Treasury since the promulgation of the first set of transfer pricing regulations in 1935, which stated "the interests controlling a group of controlled taxpayers are assumed to have complete power to cause each controlled taxpayer so to conduct its affairs that its transactions and accounting records truly reflect the net income from the property and business of each of the controlled taxpayers." n305

Moreover, the very existence of integrated multinationals is evidence that the ALS does not reflect economic reality. The predominant explanation for the existence of multinationals is the internalization theory which posits that, like any organization, multinationals exist because of market and non-market advantages that are derived from their structure. The multinational's structure allows it to avoid (internalize) transaction costs, which increases efficiency in raising capital, advertising products, achieving economies of scale, and protecting valuable intangibles. Thus, if one applies a market rate of return separately to each of the components of the multinational, the result is less than the actual return of the organization as a whole. n306 This residual, the result of the interaction among the constituent parts of the organization, cannot be assigned to any component. Any transfer pricing rule which arbitrarily assigns the residual to one part of the organization distorts economic reality. No single correct transfer price exists in this situation; instead, 
there is a continuum which depends on how the residual is split among the parties, and any price on this continuum is correct. n307

The implications of this "continuum price problem," as it is called in the economic literature, are profound. If comparables can be found, that fact indicates the multinational does not derive a large residual return from its structure because otherwise it could have driven its competitors out of the market. Thus, in these cases it would be possible to use functional analysis without having a comparable. On the other hand, where comparables cannot be found, such as in the majority of complex transfer pricing cases, that fact indicates a large residual is likely, and this residual advantage of the multinational has driven competitors out of the market. Thus, precisely in those situations arising in the majority of transfer pricing cases, where there are no comparables and therefore functional analysis is required, it will be impossible to find the "right" transfer price. Even if one performs a functional analysis based on the market returns of all the components of the multinational, a large residual will remain to be split arbitrarily among the parties. The IRS will seek to allocate all the residual to one party, the taxpayer to another, and it is likely some of it will not be taxed by any jurisdiction. n308

The White Paper contains a short chapter on "economic theories concerning the implementation of section 482," which briefly discusses the continuum price problem. n309 The chapter deals with the problem on a theoretical level by saying arm's length transactions could still be constructed by looking at the arrangements unrelated parties would have made "if they could choose to have the costs of related parties." n310 However, the White Paper does not explain either how to quantify these theoretical costs or how to allocate these costs among the related parties. On a practical level, as we have seen, the White Paper resorts to an ad hoc "profit split" in those situations where there is a residual, n311 which is really a form of unitary apportionment (but without any formula to guide it). On the other hand, by looking at the costs of developing intangibles, the final regulations do provide a formula. n312 This formula, however, is geared to leave the maximum profit in the United States, where intangibles are typically developed, and therefore is unlikely to be accepted by the rest of the world.

Beyond the theoretical critique of the ALS, which may explain some of its practical problems, one is left with the fact that the experience of the last twenty-five years indicates that the ALS creates a climate of uncertainty and an immense administrative burden for the taxpayers, the IRS and the courts and provides ample opportunity for abuse. The burden imposed by the ALS has been documented and commented upon extensively. This burden results from the need to apply the ALS on a factual, case-by-case basis, without any general rules in the majority of cases in which there are no comparables. n313 The GAO, after an extensive survey of the practical problems involved in administering the ALS on a caseby-case basis, recently concluded "transfer pricing cases in general can be very burdensome, time-consuming, and expensive for the courts, IRS, and the companies involved." n314 Former Chief Judge Nims of the Tax Court has stated that transfer pricing cases have absorbed a substantial part of the Tax Court's pretrial, trial, and post-trial resources. n315 The dollar amount of tax in controversy in section 482 cases docketed in Tax Court in 1992 was \$32 billion, twice the amount it was in 1989. n316 The figures in the appeals process are even more substantial. The costs for the government in such cases are very high and are likely to be even higher if the IRS is allowed to hire outside counsel to aid it in litigation, as has been proposed. n317 The IRS spent about \$15 million on expert witnesses in section 482 cases in 1992, and a recent Treasury report recommends increased use of such experts. n318 The Treasury report concludes that "the IRS has not been widely successful in developing and litigating section 482 cases" n319 and "for the foreseeable future, transfer pricing litigation will place a heavy burden on the Service and the Tax Court." n320

Moreover, the traditional ALS leads to a pervasive uncertainty. In the absence of clear rules, neither the taxpayer nor the IRS can know in advance the likely revenue outcome in a transfer pricing case. For the vast majority of taxpayers, the result is years of uncertainty before a case can be settled or litigated. The inability to forecast the taxes on international ventures with reasonable certainty may discourage taxpayers from undertaking such ventures despite higher potential returns. Such an inability also has multibillion dollar implications on the government's ability to plan its revenues in advance. n321

The traditional ALS also leads to the widespread possibility of abuse. While it is impossible to prove that transfer pricing underlies the widely documented and substantial disparities between the profitability of foreign controlled corporations (FCCs) and domestic corporations, there is a distinct likelihood, as recognized by the Treasury and the GAO, that multinationals are underpaying taxes in the billions as a result of the "fiscal no-man's land" created by the continuum price problem. n322 Moreover, the perception of lack of competitive fairness resulting from such 
disparities in profitability may be almost as bad as an actual underpayment of taxes by FCCs. This is because it can lead to hasty and discriminatory reactions such as the recent proposals to apply minimum profit standards only to FCCs but not to domestically controlled U.S. corporations. n323

It is likely these problems will get worse in the future despite the new final regulations, the increased resources employed by the IRS in transfer pricing cases and the new statutory penalties enacted by Congress to combat transfer price abuses. Several trends are likely to lead to an increased focus on transfer pricing in the twenty-first century. First, as trade becomes more global and multinationals proliferate, a larger proportion of such trade is conducted between affiliated corporations. Such intercompany trade accounted for nearly a third of world manufacturing trade and a quarter of world trade in the 1980's. In 1986, trade among affiliated domestic and foreign corporations accounted for 38\% of total U.S. exports and imports. n324 This globalization is likely to continue as corporations shift production of parts to locations where wages are lower. n325 Second, more of this trade consists of high technology goods; the share of such goods in world exports rose from $14 \%$ in 1966 to $22 \%$ in 1986. n326 High technology goods tend to be manufactured using intangibles unique to the multinational; therefore, comparables are unlikely to be found and the case tends to be litigated. n327

It is thus necessary to examine whether there is any viable alternative to the traditional ALS. n328 By far, the most commonly raised alternative to the ALS, and the most hotly debated, is the method used by the states in apportioning income within the United States and advocated by the House in 1962. n329 This method involves treating affiliated corporations as a single, integrated unit and apportioning the income of this unit among tax jurisdictions based on a formula measuring objective factors such as assets, payroll and sales in each jurisdiction compared to the worldwide total. n330

Two major problems are involved in designing a formulary apportionment system. The first is deciding to which taxpayers it should apply. On the state level, in order to apply formulary apportionment to affiliated corporations, the corporations must be deemed part of a "unitary business" based on the degree to which their activities are interdependent. n331 The rationale behind this requirement is formulary apportionment, predicated on the existence of a single business with synergy among the constituent parts which justify the inclusion of total income in the formula. The need to define a unitary business is considered a major disadvantage of the formulary approach because it has proven to be a source of controversy among the states and requires complicated rules. n332

Corporations under common control, however, are presumed to be able to manipulate transfer pricing to their advantage. Thus, if two corporations are under common "control," n333 and have substantial intercompany transactions (which is a prerequisite to the transfer pricing issue arising in the first place), they should be presumed to be unitary, and the allocation of income among them can be based on a common formula. n334 Otherwise, it would be relatively easy to structure a commonly controlled business in separate business units and avoid formulary allocation. The second problem is deciding which elements should be included in the formula. n335 This is the major stumbling block in reaching a consensus since each country is likely to use a formula geared to its own interests, as the United States did in the new profit split regulations which use the costs of developing intangibles, a cost likely incurred in the United States. In the absence of consensus, increased double taxation will result.

A solution may be forthcoming, however, as a result of the recent innovation in the transfer pricing field, the advance pricing agreement, or the APA. In 1991, the Service introduced an APA procedure, under which the taxpayer can suggest a transfer pricing method in advance, and if the Service agrees, the method can be applied by the taxpayer with no fear of a section 482 adjustment. n336 The APA, which resembles a provision of the 1962 House bill, encourages taxpayers to develop, before being challenged, transfer pricing methods that the Service finds acceptable, thus reducing the amount of litigation.

Some problems are present with the APA procedure. First, it is extremely complicated and costly in practice. It requires extensive submissions and documentation which is similar to the discovery process in section 482 litigation; thus only litigation costs are saved, but if the parties fail to agree, litigation is still possible. n337 Second, APAs are not published and in the absence of comparables, are not subject to any standards. n338 This leads to the impression that the Service is in effect cutting deals with well-off corporate taxpayers which remain secret and are not subject to any general standard of law or to any review. This is hardly the type of practice one wishes to encourage in a tax system based on both voluntary compliance and the impression wealthy taxpayers are subject to the same standards as everyone else. 
Despite these drawbacks, APAs represent a promising development, especially if the Service establishes published standards for applying APAs to specific industries. n339 In particular, the major transfer pricing disputes are likely to involve a relatively limited number of taxpayers. The top 350 multinationals, which control about a third of the world's productive resources, are likely to account for the vast majority of seriously disputed cases under section 482 of the Code. Thus, if the Service, acting in conjunction with the tax authorities for our major trading partners, can develop APAs (most likely based on some type of formulary profit split) with those 350 taxpayers, the greatest portion of the transfer pricing problem will be resolved. In fact, if the Service is successful, other countries which do not have the resources for effective transfer pricing enforcement can "free ride" on the Services's efforts in extracting some level of corporate tax from multinationals operating in their territory.

But what about the rest of the problem, involving smaller taxpayers who do not wish to engage in the prolonged effort to develop an APA? In those cases, a formulary solution may be used which relies on the profit split method endorsed by the final regulation. Under this method, a functional analysis is first performed and market rates of return are allocated to the ordinary functions performed by the constituent units of the taxpayer. Any residual amount is then split according to the formula, which in the case of manufacturing operations should be based half on assets and half on sales. n340 This is the formula most likely to achieve consensus between exporting and importing nations. Other formulas may be used for different industries, such as the minerals extraction industry. n341

Several objections are usually raised against any proposal for formulary apportionment. Some relate to the administrative burden formulary apportionment would impose on multinationals, which will have to compile worldwide income and sales data using United States GAAP and the United States dollar. These objections seem exaggerated. Presumably, multinationals today already have some idea of what their worldwide profit and loss accounts look like on a uniform basis. Their objections to producing such records for the Service are more likely to stem from a desire to avoid taxation than from bona fide concerns about costs. Furthermore, current laws already give the Service the means to require foreign multinationals to produce the necessary information. n342

A more serious objection to formulary apportionment, and the main reason why the GAO refused to recommend it, relates to the assertion that the traditional ALS is the current international norm, so the unilateral adoption of formulary apportionment as proposed would violate treaty obligations and lead to retaliation, double taxation, the distortion of investment decisions and the resulting loss of economic efficiency. Thus, formulary apportionment is dismissed as an impractical alternative to the ALS. Underlying this position is the assumption that international consensus cannot be reached, and the absence of consensus results in the abovelisted harms. n343 This objection also seems exaggerated. First, it is far from clear that a consensus on a formula cannot be reached, at least among the OECD countries which are our major trading partners. These nations are remarkably similar in their economic structure and all experience problems with the ALS. In fact, it seems likely that most OECD tax administrators, like the Service's international examiners, employ some formulary method in practice even while they pay lip service to the ALS. n344 Furthermore, the states have generally succeeded in agreeing to a uniform method for the division of income, embodied in the Uniform Division of Income for Tax Purposes Act, despite the wide disparities among them which are greater than those among OECD countries. n345

Second, nothing will be achieved unless the United States begins by proposing a formulary apportionment system and inviting other members of the OECD to join it. The present situation is untenable and leads to a perception, probably a reality, of massive undertaxation of multinationals. For a consensus to be achieved, one party has to take unilateral action which provides an incentive for others to act. In this regard, a useful lesson can be drawn from developments in the 1970s. After the promulgation of the section 482 regulations in 1968, in which the United States unilaterally adopted a radical new definition of the ALS, the Treasury came to realize that it could not implement them without cooperation from our major treaty partners because double taxation or increased credits for foreign taxes would occur. The result was a coordinated campaign to get the ALS, as embodied in the 1968 regulations, adopted as the international norm. This campaign culminated in the 1979 OECD report on transfer pricing, the 1976 and 1978 U.N. reports, which were heavily influenced by Stanley Surrey, and the 1983 German transfer pricing guidelines. n346

A similar effort by the United States today could have similar consequences. There are signs that this effort is already under way. As indicated above, the adoption of the CPM and the profit split method by the temporary and final regulations signals a revolution in our approach to the transfer pricing problem. This is because it indicates the abandonment of the traditional ALS based on comparables and incorporates a broad definition of "arm's length" based 
on achieving the same results unrelated parties would have reached. Once this conceptual revolution is accepted, it follows that the entire transfer pricing continuum, including formulary apportionment, is open in principle for discussion under "arm's length" methods. Indeed, the draft OECD transfer pricing report, published in 1994, endorses both the CPM, which clearly deviates from the traditional ALS as embodied in the 1979 OECD report, and the profit split, although it still rejects pure formulary methods as arbitrary. n347

The publication of the new draft OECD report, which closely reflects the final regulations, indicates the United States still maintains its influence, and any move toward accepting formulary apportionment by the United States is likely to result in similar acceptance by the other countries, at least in the relatively flexible form proposed above. In fact, acceptance of formulary apportionment as part of the transfer pricing continuum was also indicated by the result of a recent conference where senior officials of the United States Treasury, the United Kingdom Inland Revenue, the Fiscal Affairs Division of the OECD and the Japanese National Tax Administration seemed to agree

the arm's length principle and formulary apportionment should not be seen as polar extremes; rather, they should be viewed as part of a continuum of methods ranging from CUP to predetermined formulas. It is not clear where the arm's length principle ceases and formulary apportionment begins, and it is counterproductive and unimportant to attempt to apply labels to the methods. n348

This Article has sought to demonstrate the truth of this statement through the history and development of the transfer pricing problem in the United States, especially in the last twenty years. The next step is for the United States to propose discussions on the adoption of formulary techniques along the lines suggested above.

The final major objection to the unilateral adoption of a formulary method is that doing so would violate current treaties and burden the competent authority process. n349 As an initial matter, the solution would be to propose the formulary approach as a discussion draft and invite other countries to enter negotiations, but announce that the approach will be adopted unilaterally if no agreement is reached within a specified time period (e.g., five years). This period should allow sufficient time to renegotiate treaties if no agreement on the formula can be reached while, at the same time, negotiating APAs with the major multinationals along the lines outlined above.

In 1962, Congress and the Treasury decided to reject the formulary approach and adopt the traditional ALS, which the Treasury then persuaded the rest of the world to follow. This Article has attempted to demonstrate that this was a mistake resulting in over thirty years of uncertainty, arbitrariness and litigation. It is time for the United States to take the lead again in guiding the world toward a flexible formulary system of allocating worldwide taxable income of related entities, hopefully with better results.

\section{FOOTNOTES:}

n1 I.R.S. Notice 88-123, 1988-2 C.B. 458, 475 [hereinafter White Paper] (footnotes omitted). For examples of more recent statements along the same lines, see John Iekel, Samuels Defends Revenue Estimating, Arm's Length Standard, 65 Tax Notes 1587 (Dec. 26, 1994); John Turro, Treasury Continues to Champion Worldwide Arm's Length Standard, 66 Tax Notes 316 (Jan. 16, 1995).

n2 Roger Gordon \& Jeffrey Mackie-Mason, Why is there Corporate Taxation in a Small Open Economy? The Rule of Transfer Pricing and Income Shifting (National Bureau of Economic Research Working Paper No. 4690, 1994). 
n3 U.S. General Accounting Office, International Taxation: Problems Persist in Determining Tax Effects of Intercompany Prices 62-63 (1992).

n4 White Paper, supra note 1, at 459-61.

n5 H.R. Conf. Rep. No. 99-841, 99th Cong., 2d Sess. II-638 (1986).

n6 See, e.g., Treas. Reg. section 1.482-2(e)(2); Treas. Reg. section 1.482-3(b).

n7 See, e.g., Treas. Reg. section 1.482-2(e)(4); Treas. Reg. section 1.482-3(d).

n8 See, e.g., Treas. Reg. section 1.482-2(e)(3); Treas. Reg. section 1.482-3(c).

n9 For examples of recent contributions to the debate about the ALS and formulary methods, see Benjamin F. Miller, None Are So Blind as Those Who Will Not See, 66 Tax Notes 1023 (Feb. 13, 1995); John Turro, The Battle Over Arm's Length and Formulary Apportionment, 65 Tax Notes 1595 (Dec. 26, 1994); William I. Wilkins \& Kenneth W. Gideon, Memorandum to Worldwide Formulary Apportionment, 65 Tax Notes 1259 (Dec. 5, 1994); Jerome R. Hellerstein, Federal Income Taxation of Multinationals: Replacement of Separate Accounting with Formulary Apportionment, 60 Tax Notes 1131 (Aug. 23, 1993); Louis M. Kauder, The Unspecific Federal Tax Policy of Arm's Length: A Comment on the Continuing Vitality of Formulary Apportionment at the Federal Level, 60 Tax Notes 1147 (Aug. 23, 1993); Eric J. Coffill \& Prentiss Wilson, Jr., Federal Formulary Apportionment as an Alternative to Arm's Length Pricing: From the Frying Pan to the Fire? 59 Tax Notes 1103 (May 24, 1993); Benjamin F. Miller, A Reply to 'From the Frying Pan to the Fire', 61 Tax Notes 241 (Oct. 11, 1993); Reuven Avi-Yonah, Slicing the Shadow: A Proposal for Updating U.S.

International Taxation, 58 Tax Notes 1511 (Mar. 15, 1993); and Louis M. Kauder, Intercompany Pricing and Section 482: A Proposal to Shift from Uncontrolled Comparables to Formulary Apportionment Now, 58 Tax Notes 485 (Jan. 25, 1993). For a recent proposal to implement formulary methods in the context of NAFTA, see Paul R. McDaniel, Corporate Income Taxation in the North American Free Trade Zone: A Policy Perspective, Tax L. Rev (1995).

n10 This idea is stated briefly in Brian J. Arnold \& Thomas E. McDonnell, Report on the Invitational Conference on Transfer Pricing: The Allocation of Income and Expenses Among Countries, 61 Tax Notes 1377, 1381 (1993), but is not fully developed there or elsewhere. See Amicus Brief of Council of State Governments, Barclays Bank PLC v. Franchise Tax Board, 114 S.Ct. 2268 (No. 92-1384) (1994) (a brief by the present writer, outlining this idea in the context of a recent case over the constitutionality of state formulary methods).

n11 Treas. Reg. section 1.482-5.

n12 Treas. Reg. section 1.482-5(c). 
n13 White Paper, supra note 1, at 490. The profit split method has since been adopted as part of the current Treasury Regulations. See Treas. Reg. section 1.482-6.

n14 Treas. Reg. section 1.482-6(b).

n15 Treas. Reg. $\& 1.482-6(c)$.

n16 "Arm's length" does not refer to CPM, because the standard of comparability for CPM is so loose that it is doubtful whether it can truly be regarded as relying on comparables, and it has therefore been excluded from the traditional definition of the ALS.

n17 The literature on section 482 is immense. Some major articles include James P. Fuller, Section 482 Revisited, 31 Tax L. Rev. 475 (1976); James P. Fuller, Section 482: Revisited Again, 45 Tax L. Rev. 421 (1990); Richard O. Loengard, The Section 482 Pot Boils On: Comments on Recent Developments, Tax Forum No. 469 (1991); Dale W. Wickham, The New U.S. Transfer Pricing Tax Penalty: A Solution, or a Symptom of the Cause, of the International Transfer Pricing Puzzle?, 18 Int'l Tax J. 1 (1991). The best historical survey of the ALS up to 1986 is contained in Stanley I. Langbein, The Unitary Method and the Myth of Arm's Length, 30 Tax Notes 625 (Feb. 17, 1986) (focusing on the development of the ALS in the international context).

n18 See supra text accompanying note 1.

n19 T.D. 2694, 20 Treas. Dec. Int. Rev. 294, 321 (1918). See also War Revenue Act of 1917, ch. 63, 40 Stat. 300 (1917).

n20 Revenue Act of 1921, ch. 136, section 240(d), 42 Stat. 260 (1921) (reenacted in Revenue Act of 1924, ch. 234, section 240(d), 43 Stat. 288 (1924), and Revenue Act of 1926, ch. 27, section 240(f), 44 Stat. 46 (1926)). Unlike the current I.R.C. section 482, these earlier provisions allowed taxpayers to request that the Commissioner permit consolidation.

n21 "Subsidiary corporations, particularly foreign subsidiaries, are sometimes employed to 'milk' the parent corporation, or otherwise improperly manipulate the financial accounts of the parent company," H.R. Rep. No. 350, 67th Cong., 1st Sess. 14 (1921); see also S. Rep. No. 275, 67th Cong., 1st Sess. 20 (1921).

n22 For surveys of the history of I.R.C. section 482, see White Paper, supra note 1, ch. 2; Eli Lilly \& Co. v. Commissioner, 84 T.C. 996, 1114-15 (1985). 
n23 Revenue Act of 1928, ch. 852, section 45, 45 Stat. 806 (1928).

n24 Among the few changes, "Organizations" was added to "trades or businesses," "credits or allowances" were added to "gross income or deductions," and "the Secretary or his delegate may" was substituted for "the Commissioner is authorized to." See I.R.C. section 482.

n25 H.R. Rep. No. 2, 70th Cong., 1st Sess. 16-17 (1927); see also S. Rep. No. 960, 70th Cong., 1st Sess. 24 (1928).

n26 69 Cong. Rec. 605, cited in J. Seidman, Legislative History of Federal Income Tax Laws 1938-1861, 522 (1938).

n27 Id.

n28 Art. 45-1(c) of Reg. 86 (1935) (Revenue Act of 1934). The entire regulation is quoted in Essex Broadcasters, Inc. v. Commissioner, 2 T.C. 523, 528 (1943).

n29 Treas. Reg. § 1.482-1(b)(1) redesignated as Treas. Reg. § 1.482-1A(b)(1); cf. Temp. Treas. Reg. § 1.482-1T(a)(1) and (b) (1993); Treas. Reg. § 1.482-1(b)(1). See generally discussion infra Part V. The ALS was adopted under the influence of concurrent developments in international taxation and the initial evolution of model standards. See, Stanley I. Langbein, The Unitary Method and the Myth of Arm's Length, 30 Tax Notes 625, 628-34.

n30 See, e.g., Asiatic Petroleum Co. v. Commissioner, 31 B.T.A. 1152, 1159 (1935) (stating that a sale was not "arm's length" but not focusing on this issue); aff'd, 79 F.2d 234.

n31 See, e.g., G.U.R. Co. v. Commissioner, 41 B.T.A. 223 (1940) (sale of stock at seven times its market value not arm's length); aff'd, 117 F.2d 187.

n32 See, e.g., National Securities Corp. v. Commissioner, 137 F.2d 600 (3rd Cir. 1943); cert. denied 320 U.S. 794. This leading case for the application of section 45 to tax-free transfers to corporations, surveys the history of section 45 but does not mention the ALS.

n33 4 T.C. 1215 (1945).

n34 Id. at 1229. 
n35 Id. at 1232.

n36 Id. at 1233; see also Palm Beach Aero Corp. v. Commissioner, 17 T.C. 1169, 1176 (1952) ("fair consideration which reflects arm's length dealing").

n37 Grenada Industries, Inc. v. Commissioner, 17 T.C. 231, 260 (1951), aff'd, 202 F.2d 873 (5th Cir. 1953); aff'd, 346 U.S 819.

n38 The Friedlander Corp. v. Commissioner, 25 T.C. 70, 77 (1955); Motors Securities Co., Inc. v. Commissioner, 11 T.C.M. 1074, 1082 (1952).

n39 Polak's Frutal Works, Inc. v. Commissioner, 21 T.C. 953, 976 (1954).

n40 32 T.C. 390 (1959), aff'd, 294 F.2d 82 (5th Cir. 1961).

n41 Id. at 410.

n42 Id. (citing Asiatic Petroleum Co. v. Commissioner, 31 B.T.A. 1152 (1935), which did not, however, involve a direct application of the ALS).

n43 308 F.2d 520 (9th Cir. 1962).

n44 See supra note 28 and accompanying text.

n45 Frank, 308 F.2d at 528.

n46 Id. at 528-529 (citations omitted) (citing The Friedlander Corp. v. Commissioner, 25 T.C. 70,77 (1955);

Grenada Industries, Inc. v. Commissioner, 17 T.C. 231, 260 (1951); Motor Securities Co., Inc. v. Commissioner 11 T.C.M. 1074, 1082 (1972); Palm Beach Aero Corp. v. Commissioner, 17 T.C. 1169, 1176 (1952); Polak's Frutal Works, Inc. v. Commissioner, 21 T.C. 953, 975-976 (1954); and Seminole Flavor Co. v. Commissioner, 4 T.C. 1215, 1232 (1945)). 
n47 Id. at 530. Cf. Treas. Reg. 86, section 45-1(b) (1935).

n48 See e.g., The Nestle Company, Inc. v. Commissioner, 22 T.C.M. 46, 62 (1963), decided just after Frank and before Oil Base, Inc. v. Commissioner, 23 T.C.M. 1838 (1964), discussed infra note 56, in which the Tax Court analyzed the royalty rate for a valuable intangible (for which no comparables could in any case be found) in an eminently sensible way under a "reasonableness" standard, including a renegotiation of the rate to reflect profitability, without having to resort to an "arm's length" analysis. See also Ballentine Motor Co., Inc. v. Commissioner, 39 T.C. 348, 357 (1962), aff'd, 321 F.2d 796 (4th Cir. 1963) ("taxpayers owned or controlled by the same interests may enter into transactions inter se and if fair, or resulting from arm's length bargaining, such transactions will be undisturbed") (emphasis added). This decision was also rendered shortly after Frank.

n49 Hearings on the President's 1961 Tax Recommendations Before the Committee on Ways and Means, 87th Cong., 1st Sess., vol. 4 at 3549 (1961) (statement of Commissioner Caplin); see Stanley I. Langbein, supra note 17, at 643-44. These concerns are remarkably similar to those voiced currently. See, e.g., Richard L. Kaplan, Treasury Blasted over Alleged Transfer Pricing Shenanigans, 55 Tax Notes 150 (Apr. 13, 1992); Richard L. Kaplan, International Tax Enforcement and the Special Challenge of Transfer Pricing, U. Ill. L. Rev. 299 (1990).

n50 H.R. 10650, 87th Cong., 2d Sess. section 6 (1962). Important among the other provisions that were introduced to curb transfer pricing abuses was subpart F, adopted in 1962. I.R.C. sections 952-964. This provision defines the income of controlled foreign corporations that is not eligible for tax deferral and for which dividends to the U.S. parent must be imputed. For a brief overview of the relationship between I.R.C. section 482 and subpart F, see Richard L. Kaplan, supra note 49 at 307-311.

n51 H.R. 10650, 87th Cong., 2d Sess. section 6 (1962).

n52 H.R. Rep. No. 1447, 87th Cong., 2d Sess. 28 (1962).

n53 See, e.g., Hearings on H.R. 10650 before the Senate Committee on Finance, 87th Cong., 2d Sess. 560-61, 725-26 (1962) [hereinafter Hearings] (statements by W. Slowinski and R. Landolt).

n54 H.R. Rep. No. 2508, 87th Cong, 2d Sess. 18-19, reprinted in 1962 U.S.C.C.A.N. 3732, 3739.

n55 Regulations, which did not accept the invitation to use a formula approach, were proposed in 1965, Prop. Treas. Reg. \&\& 1.482-1(d) and 2, 30 Fed. Reg. 4256 (Mar. 31, 1965) (these regulations did not include any provisions on sales of tangibles), withdrawn and reproposed in 1966, Prop. Treas. Reg. §§ 1.482-1(d) and 2, 31 Fed. Reg. 10394 (Mar. 31, 1966), and issued in final form in 1968, Treas. Reg. § 1.482. See discussion infra text accompanying note 71. 
n56 Oil Base, Inc. v. Commissioner, 23 T.C.M. (CCH) 1838 (1964).

n57 Id. at 1845-46. (citations omitted).

n58 Oil Base, Inc. v. Commissioner, 362 F.2d 212, 214 (9th Cir. 1966) (footnote omitted).

n59 Id. at 214 n.5.

n60 See Hearings, supra note 53, at 3549; Langbein, supra note 17, at 643-44.

n61 24 T.C.M. (CCH) 1542 (1965).

n62 Id. at 1556.

n63 Id. (citing Treas. Reg. section 1.482-(b)(1)).

n64 Id. at 1556 \& n.3 (1965) (Oil Base is not cited).

n65 Id. at 1557.

n66 372 F.2d 990 (1967).

n67 Id. at 997.

n68 Id. at 1000.

n69 Id. at 997. 
n70 See also Young \& Rubicam, Inc. v. United States, 410 F.2d 1233 (1969) (applying the ALS to services on the basis of Eli Lilly and Oil Base, but doing so without comparables).

n71 T.D. 6952, 1968-1 C.B. 218 (1968). See Stanley S. Surrey, Treasury's Need to Curb Tax Avoidance in Foreign Business Through Use of 482, $28 \mathrm{~J}$. Tax'n 75 (1968) (discussing the policy behind these regulations).

n72 See T.D. 8470, 1993-1 C.B.90 (1993).

n73 This may have been the result of Assistant Secretary Surrey's adherence to the ALS. Treasury may also have felt that it lacked the authority to promulgate a formulary system. See Langbein, supra note 17, at 648.

n74 On the "radical" nature of the regulations and their departure from earlier models see Langbein, supra note 17, at 645-46. These regulations underlay the successful U.S. attempt to establish the ALS as the international "norm," as reflected in the White Paper, supra note 1 and accompanying text. See Langbein, supra note 17, at 646-54.

n75 Treas. Reg. section 1.482-2(b)(3).

n76 Treas. Reg. section 1.482-2(d)(2).

n77 Treas. Reg. § 1.482(e)(1)(ii).

n78 Treas. Reg. section 1.482-2(e)(2)-(4).

n79 Treas. Reg. section 1.482-2(e)(1)(iii). This language did not appear in the 1966 version of the regulations, which did not say what should be done in the absence of comparables. See Prop. Treas. Reg. section 1.482-2, 31 Fed. Reg. 10394 (1966).

n80 55 T.C. 56 (1970).

n81 Id. at 65-68. 
n82 435 F.2d 182 (1970).

n83 Id. at 186-87.

n84 Id.

n85 304 F.Supp. 627 (N.D. Ill. 1969), aff'd in part and rev'd in part, 452 F.2d 445 (7th Cir. 1971).

n86 Id. at 634.

n87 Id. at 644-45.

n88 U.S. Gypsum Co. v. United States, 452 F.2d 445, 449 (7th Cir. 1971).

n89 Id. at $448-49$.

n90 Id. at 449.

n91 Id.

n92 55 T.C. 928 (1970).

n93 Id. at 993.

n94 Id. at 994-95.

n95 Id. at 997-98. The PPG Industries case is significant in two other respects: it represents an early attempt by the Commissioner to deviate from the ALS and to use industry statistics (prefiguring the current treasury regulations), and it represents an early case of functional analysis and profit split by the court (prefiguring the White Paper). 
n96 60 T.C. 569 (1973).

n97 Id. at 599. Note that the ALS has by now, in the view of the Tax Court, been incorporated into the statute. This is also evidenced by a series of related cases in which the Commissioner attempted unsuccessfully to hold the taxpayer to customs valuations. See, e.g., Brittingham v. Commissioner, 66 T.C. 373, (1976), aff'd, 598 F.2d 1375 (5th Cir. 1979); Dallas Ceramic Co. v. United States, 74-2 USTC (CCH) 19830 (N.D. Tex. 1974), rev'd, 598 F.2d 1382 (5th Cir. 1979).

n98 Ross Glove Co., 60 T.C. at 602.

n99 468 F.2d 805 (5th Cir. 1972).

n100 Id. at 806-07.

n101 Id.

n102 Id. at 808.

n103 See supra text accompanying note 46.

n104 If one takes only the cases surveyed in the White Paper, supra note 1, and the few major cases decided between 1988 and 1992, one finds that up to 1973, the ALS based on comparable transactions was employed in 9 of 14 cases (64\%). From 1974 onward, comparables were found only in 4 of 13 major section 482 cases (31\%). In all of these four cases (Eli Lilly \& Co. v. Commissioner, 856 F.2d 855 (7th Cir. 1988); Paccar, Inc. v. Commissioner, 85 T.C. 754 (1985); U.S. Steel Corp. v. Commissioner, 617 F.2d. 942 (2nd Cir. 1980); and Bausch \& Lomb Inc. v. Commissioner, 933 F.2d 1084 (2nd Cir. 1991)) the Service argued that the comparable was inappropriate, and in U.S. Steel and Bausch \& Lomb, it attempted to reverse the result in the proposed and temporary regulations.

The White Paper cites the following cases decided prior to 1973: National Securities Corp. v. Commissioner, 137 F.2d 600 (3rd. Cir), cert. denied, 320 U.S. 794 (1943); Hall, 294 F.2d 82; Nestle Co. v. Commissioner, 22 T.C.M. (CCH) 46; Oil Base, Inc., 362 F.2d 212; Johnson Bronze Co., 24 T.C.M. 1542; Eli Lilly \& Co., 372 F.2d 990; Young \& Rubicam, 410 F.2d 1223; U.S. Gypsum, 452 F.2d 445; Woodward Governor Co., 55 T.C. 56; Baldwin-LimaHamilton Corp., 435 F.2d 182; PPG Industries Inc., 55 T.C. 928; Lufkin Foundry \& Mach. Co., 468 F.2d 805; Ross Glove Co., 60 T.C. 569; and R.T. French Co. v. Commissioner, 60 T.C. 836 (1973). The White Paper cites the following cases decided after 1974: Dallas Ceramic Co. v. United States, 598 F.2d 1382 (5th Cir. 1979); Cadillac Textiles, Inc. v. Commissioner, 34 T.C.M. 295 (1975); Edwards v. Commissioner, 67 T.C. 224 (1976); E.I. DuPont de Nemours \& Co. v. United States, 608 F.2d 445 (Ct. Cl. 1979); U.S. Steel Corp. v. Commissioner, 617 F.2d 942 (2nd Cir. 1980);

Hospital Corp. of America v. Commissioner, 81 T.C. 520 (1983); Eli Lilly \& Co. v. Commissioner, 856 F.2d 855 (7th Cir. 1988); Ciba-Geigy Corp. v. Commissioner, 85 T.C. 172 (1985); Paccar, Inc. v. Commissioner, 85 T.C. 754 (1985); 
G.D. Searle \& Co. v. Commissioner, 88 T.C. 252 (1987). Major cases decided between 1988 and the issuance of the proposed regulations in 1992 are Bausch \& Lomb, Inc. v. Commissioner, 933 F.2d 1084 (1989); Sunstrand Corp. v. Commissioner, 96 T.C. 226 (1991); Merck \& Co. Inc. v. United States, 24 Cl.Ct 73, 91-2 USTC 150,456, at 89,736 (1991). Of these cases, comparables were used only in U.S. Steel, Eli Lilly (for one year), Paccar and Bausch \& Lomb.

The White Paper, reports that in international examinations generally, "fourth methods" were used $36 \%$ of the time, see White Paper, supra note 1, at 502, and that other estimates of this figure range from $14 \%$ to $47 \%$. Id. at 463. However, the most telling number is that in an astounding 91\% of the cases examined, the taxpayers did not use comparables in establishing transfer prices. Id. at 502. See also U.S. General Accounting Office, IRS Could Better Protect U.S. Tax Interests in Determining the Income of Multinational Corporations 29 (1981) (finding that of 403 cases studied, in dollar terms, the CUP method based on direct comparables accounted for only $3 \%$ of the adjustments).

n105 The following discussion is based on cases decided between 1973 and the issuance of the proposed regulations in 1992. Since 1992, there have been several more section 482 cases based on the old regulations, and the results have been similar to those described in the text. However, the IRS has been slightly more successful, as the litigating skills utilized in section 482 cases have improved. See, e.g., Perkin-Elmer Corp. v. Commissioner, 66 T.C.M. (CCH) 634 (1993); Seagate Technology, Inc. v. Commissioner, 102 T.C. 149 (1994); and National Semiconductor Corp. v. Commissioner, 67 T.C.M. (CCH) 2849 (1994).

n106 60 T.C. 836.

n107 Id. at 838-39.

n108 R.T. French Co., 60 T.C. at 836-837 (citing Nestle Co. v. Commissioner, 22 T.C.M. (CCH) 46 (1963)) (the Service was in the unusual position of arguing that royalties to a foreign parent were too low).

n109 Id. at 851.

n110 Id. at 852-54.

n111 Id. at 849-50.

n112 617 F.2d 942 (2nd Cir. 1980).

n113 Id. at 945. 
n114 Id. at 942.

n115 Id. at 947.

n116 Id. at 949-50.

n117 Id. at 949.

n118 Id. at 950-51 (footnotes omitted).

n119 Oil Base, Inc. v. Commissioner, 23 T.C.M. (CCH) 1838, 1845-46 (1964); see supra text accompanying notes 5859.

n120 See Prop. Treas. Reg. section 1.482-2(e)(2)(ii); Temp. Treas. Reg. section 1.482-1T(e)(3)(iii); Temp. Treas. Reg. section 1.482-3T(b)(2)(ii)(B) \& (iv); Treas. Reg. section 1.482-1(d)(3)(ii)(C).

n121 92 T.C. 525 (1989).

n122 Id. at 525, 580.

n123 Id. at 580-81.

n124 Id. at 584.

n125 Id. at 589-91.

n126 Id. at 592-93.

n127 Id. at 601. 
n128 Id. at 594-611.

n129 Bausch \& Lomb, 933 F.2d at 1084.

n130 Id. at 1091.

n131 The Second Circuit also affirmed the Tax Court's "best judgment" royalty determination under a "not clearly erroneous" standard. The Second Circuit's opinion in Bausch \& Lomb, as well as the Claims Court's opinion in Merck \& Co. v. United States, 24 Cl. Ct. 73, 91-2 USTC 150,456, in effect declare that the ALS is economically if not legally inapplicable to an integrated multinational. See infra part IV.

n132 See R.T. French Co., 60 T.C. at 836; Bausch \& Lomb, Inc., 933 F.2d at 1084.

n133 See U.S. Steel Corp., 617 F.2d at 942; Bausch \& Lomb, 933 F.2d at 1084.

n134 Even when the comparables are closer, many adjustments are usually needed. In Eli Lilly \& Co. v. Commissioner, 84 T.C. 996, 1176-86 (1985), for the one year in which a comparable existed, the Tax Court discussed the necessary adjustments over eleven pages, and reached the conclusion that a $66 \%$ discount from the "comparable" price was needed! But cf. Paccar, Inc. v. Commissioner, 85 T.C. 754 (1985) (Tax Court accepted the taxpayer's proposed comparable with only minimal adjustments).

n135 34 T.C.M. (CCH) 295 (1975).

n136 Id. at 305 (citing Treas. Reg. section 1.482-2(b)) (defining the arm's length allocation for the performance of services).

n137 Id. at 305-06.

n138 Id. at 306.

n139 White Paper, supra note 1, at 490. 
n140 Treas. Reg. section 1.482-6.

n141 Cadillac Textiles Inc., 34 T.C.M. at 306.

n142 See, e.g., Edwards v. Commissioner, 67 T.C. 224 (1976). In Edwards, another domestic section 482 case, the Commissioner argued for a profit split, and the Tax Court rejected this suggestion as incompatible with the ALS, but relied on profits from an uncontrolled sale: "The focus is not, as suggested by respondent, on determining an acceptable or reasonable overall gross profit percentage, but is on determining an arm's-length price for the sale or sales in question by using the gross profit percentage established in an uncontrolled sale." Id. at 236-37.

n143 608 F.2d 445 (Ct. Cl. 1979).

n144 Id. at 447 n.4.

n145 Id. at 449-51.

n146 Id. at 455.

n147 Id. at 456.

n148 Treas. Reg. section 1.482-5; Temp. Treas. Reg. section 1.482-5T (1993); Prop. Treas. Reg. section 1.4822(f), 57 Fed. Reg. 3571 (Jan. 30, 1992).

n149 E.I. Du Pont de Nemours \& Co., 608 F.2d at 461-62.

n150 81 T.C. 520 (1983).

n151 Id. at 577.

n152 Id. at 578-87. 
n153 Id. at 592-95.

n154 Id. at 596-601.

n155 See Treas. Reg. section 1.482-2(b)(8) (intangible regulations should apply in such cases of services combined with knowhow); preamble to Prop. Treas. Reg. section 1.482-2(e) (Jan. 30, 1992).

n156 84 T.C. 996 (1985), aff'd in part, rev'd in part and remanded, 856 F.2d 855 (7th Cir. 1988).

n157 See generally, J. Tomas Hexner \& Glenn P. Jenkins, Puerto Rico and Section 936: A Costly Dependence, 10 Tax Notes Int'l 235 (1995) (discussing the relationship between transfer pricing and tax benefits for subsidiaries of U.S. corporations, operating in Puerto Rico).

n158 Eli Lilly \& Co., 84 T.C. at 996.

n159 Id. at 1123.

n160 Id. at 1126.

n161 Id. at 1130.

n162 Id. at 1151, 1167.

n163 Id. at 1107, 1167.

n164 Eli Lilly \& Co., 856 F.2d at 855.

n165 Id. at 863. 
n166 Id. at 871-72.

n167 See discussion infra Part IV.

n168 88 T.C. 252 (1987).

n169 Id. at 366-67.

n170 Id. at 370.

n171 Id. at 376.

n172 Id. at 375.

n173 85 T.C. 172 (1985).

n174 Id. at 222.

n175 Id. at 237.

n176 Id. at 226.

n177 96 T.C. 226 (1991).

n178 24 Cl. Ct. 73 (1991).

n179 Sundstrand, 96 T.C. at 356-57. 
n180 Id. at 374.

n181 Id. at 374-75.

n182 Id. at 395.

n183 24 Cl. Ct. 73.

n184 Id. at 91.

n185 Id. at 84-85.

n186 Id. at 85.

n187 Id. at 86.

n188 Id. at 88.

n189 Id. at 91. For another example of a court, this time the Tax Court, interposing its judgment over that of the Service in an R\&D context, see Westreco, Inc. v. Commissioner, 64 T.C.M. (CCH) 849 (1992).

n190 G.D. Searle, 88 T.C. at 370.

n191 Merck, 24 Cl. Ct. at 86.

n192 In Proctor \& Gamble Co. v. Commissioner, 95 T.C. 323 (1990), aff'd, 961 F.2d 1255 (6th Cir. 1992), the Tax Court reversed the Commissioner's section 482 royalty allocation from P\&G Spain to its Swiss parent, which had provided P\&G Spain with substantial technical assistance, because P\&G Spain was forbidden from paying royalties under Spanish law. This case illustrated the irrelevance of the ALS; clearly, no unrelated party would have provided the assistance to P\&G Spain knowing it could not by paid under Spanish law. The issue under section 482 should be the 
economic allocation of income, not whether a royalty could by paid. For a similar result under even more egregious circumatances, see Exxon Corp. v. Commissioner, 66 T.C.M. (CCH) 1707 (1993), where the Tax Court refused to allow the Service to allocate intercompany oil sales between Exxon subsidiaries based on Saudi Arabian price controls set, at the time, below the prevailing market price. Id. at 1760. Exxon thus escaped the effect of the price restrictions on its income allocation despite demonstrations made by the Service that Exxon had flouted those restrictions. Id. at 1752-60.

n193 I.R.C. section 936(h)(5).

n194 Joint Comm. on Taxation, 97th Cong., 2d Sess., General Explanation of the Revenue Provisions of the Tax Equity and Fiscal Responsibility Act of 1982, 82-96 (Comm. Print 1983).

n195 I.R.C. section 367(d)(2)(A).

n196 H.R. Rep. No. 426, 99th Cong., 1st Sess. 423-24 (1985) (footnote omitted).

n197 H.R. 3838, 99th Cong., 1st Sess. (1985). A similar "commensurate with income" standard was applied to section 367(d) transfers of intangibles and to section 936(h) cost sharing payments.

n198 H.R. Rep. No. 426 at 424 (emphasis added).

n199 Id. at 425 (emphasis added).

n200 H.R. Conf. Rep. No. 841, 99th Cong., 2nd Sess. II-637 (1986), reprinted in 1986 U.S.C.C.A.N. 4075, 4725. The conference also adopted a Senate provision, enacted as section 1059A of the Code, which aimed to prevent the disparities between high transfer prices and low custom valuations at issue in Brittingham v. Commissioner, 598 F.2d 1375 (5th Cir. 1979).

n201 H.R. Conf. Rep. No. 841 at II-638, reprinted in U.S.C.C.A.N. at 4726.

n202 White Paper, supra note 1.

n203 Prop. Treas. Reg. section 1.482, 57 Fed Reg. 3571 (Jan. 30, 1992). 
n204 Temp. Treas. Reg. section 1.482T (1993).

n205 Treas. Reg. section 1.482.

n206 White Paper, supra note 1, at 459-61.

n207 Id. at 461-65.

n208 Id. at 464-65.

n209 Id. at 466-68.

n210 Id. at 469-71.

n211 Id. at 472-80.

n212 Id. at 481.

n213 Id. at 488.

n214 Id. at 488-89.

n215 Id. at 489.

n216 Id.

n217 Id. at 490. 
n218 Id. at 490.

n219 Id.

n220 See Loengard, supra note 17.

n221 White Paper, supra note 1, at 475.

n222 Id.

n223 Id. at 488.

n224 Id. at 475-77.

n225 Id. at 483-85.

n226 Id. at app. C.

n227 Id. at 477-78.

n228 See supra text accompanying notes 195-96.

n229 White Paper, supra note 1 , at 477-78.

n230 Organization for Economic Co-operation and Development, Transfer Pricing and Multinational Enterprises, 52 (1979) [hereinafter OECD Report].

n231 Id. at 54 ("The profit comparison approach thus remains more in the nature of an indication that the consideration charged for the use of intangible property may or may not be reasonable."); see also, Id. at 52 ("It is 
considered that it is unlikely to be possible to construct any standard rates ... as even within a given sector of industry it is extremely difficult to discern any typical rate or range of rates.").

n232 See Langbein, supra note 17, at 654-55; Stanley I. Langbein, Langbein Blasts Arm's Length Method as Unworkable, Tax Analysts Highlights \& Documents, Aug. 24, 1990 [hereinafter Langbein, Langbein Blasts Arm's Length Method]. See also discussion infra part V (analyzing the implications of this "continuum price problem").

n233 See Treas. Reg. § 1.482-6. See also infra text accompanying notes 234-52.

n234 See, e.g., Richard L. Kaplan, International Tax Enforcement and the Special Challenge of Transfer Pricing, 1990 U. Ill. L. Rev. 299 (1990); Richard T. Rapp, Pitfalls in the BALRM, 49 Tax Notes 703 (1990) (arguing the standards of the BALRM are not easily met in the real world).

n235 See, e.g., Rapp, supra note 234, at 706-07.

n236 See White Paper, supra note 1, at 464.

n237 Preamble to Prop. Treas. Reg. section 1.482, 57 Fed. Reg. 3571, 3572 (Jan. 30, 1992).

n238 Prop. Treas. Reg. section 1.482(f), 57 Fed. Reg. 3571, 3586 (Jan. 30, 1992).

n239 Prop. Treas. Reg. section 1.482-2(d)(1)(iii), 57 Fed. Reg.3571, 3579 (Jan. 30, 1992).

n240 Prop. Treas. Reg. section 1.482-2(d)(3), 57 Fed. Reg. 3571, 3580 (Jan. 30, 1992).

n241 Prop. Treas. Reg. section 1.482-2(d)(2)(iii), 57 Fed. Reg. 3571, 3579 (Jan. 30, 1992).

n242 Prop Treas. Reg. § 1.482-2(d)(4)(i), 57 Fed. Reg. 3571, 3581 (Jan 30 1993).

n243 Prop. Treas. Reg. section 1.482-2(d)(4)(iii), 57 Fed. Reg. 3571, 3582 (Jan. 30, 1992). 
n244 Prop. Treas. Reg. section 1.482-2(d)(4)(i).

n245 Prop. Treas. Reg. section 1.482-2(e)(1)(ii), 57 Fed. Reg. 3571, 3586 (Jan. 30, 1992).

n246 The CUP method described was a holdover from Treas. Reg. section 1.482-2(e)(2)(ii), which was in force during the promulgation of the proposed regulations.

n247 Prop. Treas. Reg. section 1.482-2(e)(1)(iii), 57 Fed. Reg. 3571, 3586 (Jan. 30, 1992).

n248 Prop. Treas. Reg. section 1.482-2(e)(1)(iii)-(iv), 57 Fed. Reg. 3571, 3586 (Jan. 30, 1992).

n249 Prop. Treas. Reg. section 1.482-2(f)(4), 57 Fed. Reg. 3571, 3587 (Jan. 30, 1992).

n250 Prop. Treas. Reg. section 1.482-2(f)(5), 57 Fed. Reg. 3571, 3587 (Jan. 30, 1992).

n251 Prop. Treas. Reg. section 1.482-2(f)(6), 57 Fed. Reg. 3571, 3587 (Jan. 30, 1992).

n252 Prop. Treas. Reg. section 1.482-2(f)(7), 57 Fed. Reg. 3571, 3589 (Jan. 30, 1992).

n253 Prop. Treas. Reg. section 1.482-2(f)(8), 57 Fed. Reg. 3571, 3590 (Jan. 30, 1992).

n254 Prop. Treas. Reg. section 1.482-2(f)(9), 57 Fed. Reg. 3571, 3590 (Jan. 30, 1992).

n255 Prop. Treas. Reg. section 1.482-2(f)(2), 57 Fed. Reg. 3571, 3587 (Jan. 30, 1992).

n256 See infra text accompanying note 265.

n257 See White Paper, supra note 1, at 476. 
n258 OECD Report, supra note 230, at 14-15.

n259 Id. at 15 (emphasis added).

n260 White Paper, supra note 1, at 476 ("Nowhere, however, does the OECD report suggest that the profits of the related enterprises are irrelevant to this determination"). Id.

n261 Prop. Treas. Reg. $\S$ 1.482-2(d)(4)(iii), 57 Fed. Reg. 3571, 3581 (Jan. 30, 1992).

n262 Prop. Treas. Reg. section 1.482-2(d)(4)(iii), 57 Fed. Reg. 3571, 3581 (Jan. 30, 1992).

n263 Prop. Treas. Reg. section 1.482-2(e)(1)(ii), 57 Fed. Reg. 3571, 3585 (Jan. 30, 1992).

n264 Prop. Treas. Reg. section 1.482-2(f)(1), 57 Fed. Reg. 3571, 3586 (Jan 30, 1992).

n265 OECD Report, supra note 230, at 19. The effect of the arm's length approach advocated by the OECD Report is "to recongize the actual transactions as the starting point for tax assessment and not, in other than exceptional cases, to substitute other transactions for them". Id.

n266 For an analysis of the reactions of trading partners, see International Chamber of Commerce Opposing Proposed Transfer Pricing Rules, Daily Tax Rep. (BNA) No. 69, at G7 (April 9, 1992); Proposed Transfer Pricing Regulations Could Spark Tax War, Experts Say, Daily Tax Rep. (BNA) No. 115, at G-1 (June 15, 1992). See also U.S. Trading Partners Respond Favorably to Proposed Section 482 Regs, 95 Tax Notes Today 55-17, March 11, 1992 (a somewhat misleading title in light of the reactions actually reported).

n267 See H.R. Rep. No. 426 at 425.

n268 International Chamber of Commerce Opposing Proposed Transfer Pricing Rules, Daily Tax Rep. (BNA) No. 69, at G-7 (April 9, 1992).

n269 See generally New York State Bar Assoc. Tax Section, Comments on Proposed Section 482 and Cost Sharing Regulations (Sept. 9, 1992); D. Kevin Dolan, Proposed Transfer Pricing and Cost Sharing Regulations, 21 Tax Mgmt. 
Int'l J. 171 (1992); Elizabeth King, The Section 482 White Paper and the Proposed Regulations: A Comparison of Key Provisions, 4 Tax Notes Int'l 331, 334 (1992); Steven P. Hannes, An Examination of the New U.S. Transfer Pricing Proposals, 4 Tax Notes Int'l 281, 282 (1992); James P. Fuller \& Ernest F. Aud, Jr., The Proposed Section 482 Regulations, 4 Tax Notes Int'l 599, 600 (1992).

n270 Service Promises Section 482 Review, Leniency Administrating Payroll Tax Rules, 92 Tax Notes Today 180-1, Sept. 3, 1992.

n271 For analyses of the temporary regulations see James P. Fuller \& Ernest F. Aud Jr., The New Temporary and Proposed Section 482 Regulations: A Wolf in Sheep's Clothing?, 6 Tax Notes Int'l 525 (1993); Steven P. Hannes, An Evaluation of IRS's 1993 Transfer Pricing and Related Penalty Proposals: Round Three, 6 Tax Notes Int'l 397 (1993); Victor Zonana, Section 482: The 1993 Regulations: Once More, With Feeling!, Tax Club Paper, Feb. 9, 1993.

n272 Temp. Treas. Reg. section 1.482-1T(b)(1) (1993); Treas. Reg. sections 1.482-1(b)(1)-(2) (emphasizing "arm's length results"). Compare with Prop. Treas. Reg. section 1.482-1(b)(1), 57 Fed. Reg. 3571, 3578 (Jan. 30, 1992), which subjected the ALS to a "sound business judgment on the basis of reasonable levels of experience" test, the "reasonableness" test of Frank v. International Canadian Corp., 308 F.2d 520, 528-529 (1962), which had been rejected by the Service since 1935. See supra text accompanying notes 43-47.

n273 Temp. Treas. Reg. section 1.482-1T(b)(2)(iii) (1994); Treas. Reg. section 1.482-1(c).

n274 Id.

n275 Temp. Treas. Reg. section 1.482-1T(b)(2)(iii)(C), Example 1 (1993); cf. Treas. Reg. section 1.482-8, Example 1.

n276 Id.

n277 Temp. Treas. Reg. section 1.482-1T(b)(2)(iii)(C), Example 2 (1993).

n278 Fuller \& Aud, supra note 271, at 527. The example was dropped from the final regulations, but under the examples that were included, the CUP (and CUT for intangibles) apply only where identical comparables are found, so that the CPM will apply in most cases under the BMR. See Treas. Reg. section 1.482-8.

n279 See Prop. Treas. Reg. section 1.482, 58 Fed. Reg. 5263, 5265 (Intro. to Temp. Treas. Reg.) (Jan. 21, 1993) (noting the criticism that "elevating CPM to such a high level of priority was inconsistent with" the ALS); see also John 
Turro, An Interview with U.S. Treasury International Tax Counsel Jim Mogle, 6 Tax Notes Int'l 303 (1993) (the International Tax Counsel accepts the criticism).

n280 Temp. Treas. Reg. section 1.482-3T(a)(1)-(5) (1993).

n281 Temp. Treas. Reg. section 1.482-3T(b)(1) (1993).

n282 Temp. Treas. Reg. section 1.482-3T(b)(2)(i) (1993).

n283 Temp. Treas. Reg. section 1.482-1T(c)(2)(ii) (1993); cf. Treas. Reg. section 1.482-3(b)(2)(II).

n284 Temp. Treas. Reg. sections 1.482-3T(c)(3)(i), 1.482-3T(d)(3)(i) (1993) (both stating "close physical similarity of the property involved in the controlled and uncontrolled transactions is not ordinarily necessary" for the resale price and cost plus methods, respectively).

n285 Temp. Treas. Reg. sections 1.482-3T(c)-(d) (1993); cf. Treas. Reg. sections 1.482-3(c)-(d). The taxpayer is unlikely to use "other methods" despite the permission given in the temporary regulations, Temp. Treas. Reg. section 1.482-3T(e) (1993), and the final regulations, Treas. Reg. section 1.482-3(e), because such methods do not satisfy the "reasonable belief" standard of the attendant penalty provisions. See Treas. Reg. section 1.6662-5(j)(5)(iii), which subject the taxpayer to draconian penalties of 20 or 40 percent of the underpayment. I.R.C. sections 6662(a), (h)(1).

n286 Temp. Treas. Reg. section 1.482-4T(c) (1993); cf. Treas. Reg. section 1.482-4(c).

n287 Temp. Treas. Reg. section 1.482-4T(c)(2)(ii)(A) (1993); cf. Treas. Reg. section 1.482-4(c)(2)(iii). In addition, the comparable transfer must meet a stringent list of "comparable circumstances." Temp. Treas. Reg. section 1.4824T(c)(2)(ii)(B) (1993); cf. Treas. Reg. section 1.482-4(c)(2)(iii)(B).

n288 Theoretically, the taxpayer can use "other methods," but once again, their use is constrained by the risk of penalties. I.R.C. section 6662. See Fuller \& Aud, supra note 271, at 540 ("The effect is all too clear: since CUT is very narrow and 'other' methods may not be penalty proof, the regulations have a strong bias towards the use of CPM").

n289 Temp. Treas. Reg. section 1.482-5T(c)(1) (1993); cf. Treas. Reg. section 1.482-5(c).

n290 Temp. Treas. Reg. section 1.482-5T(c)(1) (1993); cf. Treas. Reg. section 1.482-5(c). 
n291 Temp. Treas. Reg. section 1.482-5T(d)(2)(ii) (1993); cf. Treas. Reg. section 1.482-1(e)(2).

n292 OECD Report, supra note 230, at 15. Predictably, our trading partners objected that the temporary regulations "are still not fully consistent with the internationally accepted arm's length standard." Korean Finance Ministry Comments on Transfer Pricing Regs., Tax Notes Today, Aug. 31, 1993. See also German Industry Rep Takes Aim at Proposed Regs., Tax Notes Today, Aug. 5, 1993; Keidanren Urges IRS to Take Another Look at Proposed Regs., Tax Notes Today, July 29, 1993.

n293 Intercompany Transfer Pricing Regulations under Section 482, Highlights \& Documents, July 5, 1994 at 117. On the final regulations, see George N. Carlson et al., The Final Transfer Pricing Regulations: The More Things Change, The More They Stay the Same, Tax Notes Today, July 29, 1994; Stephen P. Hannes, IRS 1994 Transfer Pricing Rules Reward Planning and Documentation, Increase Penalty Risks, Tax Notes Today, Aug. 1, 1994.

n294 Treas. Reg. section 1.482-1(b)(1).

n295 Treas. Reg. section 1.482-1(c)(1) (emphasis added).

n296 Carlson et al., supra note 293, at XIII.

n297 John Turro, Mogle Comments on Finalized Transfer Pricing Regulations, Tax Notes Today, July 6, 1994.

n298 Hannes, supra note 293; see also Foreign Tax Officials Discuss Final Transfer Pricing Regs., Tax Notes Today, Sept. 30, 1994 (expressing foreign concerns regarding the United States' use of the CPM under the 1994 regulations).

n299 Treas. Reg. section 1.482-6.

n300 Commentators have noted that the profit split method based on comparables is unlikely to be used. See, e.g., Carlson et al., supra note 293, at VII.

n301 Treasury Release on Final Section 482 Regulations, Tax Notes Today, July 6, 1994 (emphasis added). 
n302 933 F.2d 1084 (2nd Cir. 1991).

n303 24 Cl. Ct. 73 (1991).

n304 See, e.g., Note, Multinational Corporations and Income Allocation Under Section 482 of the Internal Revenue Code, 89 Harv. L. Rev. 1202 (1976); Langbein, supra note 17; Daniel J. Frisch, The BALRM Approach of Transfer Pricing, 42 Nat'l Tax J. 261 (1989); Stanley I. Langbein, Transaction Cost, Production Cost, and Tax Transfer Pricing, 44 Tax Notes 1391 (Sept. 18, 1989); United States General Accounting Office, International Taxation: Problems Persist in Determining Tax Effects of Intercompany Prices (1992) [hereinafter, GAO, International Taxation]; Dale W. Wickham and Charles J. Kerester, New Directions Needed for Solution of the International Transfer Pricing Tax Puzzle: Internationally Agreed Rules or Tax Warfare?, 56 Tax Notes 339 (July 20, 1992).

n305 Art. 45-1(b) of Reg. 86 (1935). The Treasury continues to recognize this fact today as indicated in Treas. Reg. section 1.482-1(b)(1). See also H.R. Rep. No. 426, at 423-24.

n306 For a lucid recent summary of the internalization theory, see Christos Pitelis \& Roger Sugden, The Nature of the Transnational Firm (1991).

n307 GAO, International Taxation, supra note 304, at 61-62; Langbein, Langbein Blasts Arm's Length Method, supra note 232; Langbein, supra note 17, at 636; Wickham and Kerester, supra note 304, at 345-47.

n308 Langbein, supra note 17, at 654-55, 666. One may argue that the reason the IRS lost cases like Bausch \& Lomb, 933 F.2d at 1084, was that the judges agreed there was a residual which did not derive from the functions performed by the overseas affiliate but did not see why this residual needed to be allocated to the United States (other than because of its higher effective tax rate). See supra text accompanying notes 117-30.

n309 White Paper, supra note 1, at 483.

n310 Id.

n311 Id. at 490.

n312 Treas. Reg. section 1.482-6. 
n313 See, e.g., GAO, International Taxation, supra note 304, at ch. 3; Wickham \& Kerester, supra note 304, at 34955.

n314 GAO, International Taxation, supra note 304, at 47. In a recent transfer pricing case, Chevron produced 1.3 million pages of unlabelled documents to the IRS. See Bureau of National Affairs, Tax Management Transfer Pricing Report, 135-36 (July 7, 1993).

n315 I.R.S. Official Says No APA Disclosure, But Generic Information to Be Provided, Tax Notes Today, March 30, 1992.

n316 Id.

n317 Spending Bill Would Let IRS Use Outside Attorneys to Argue Section 482 Cases, Daily Tax Rep. (BNA) No. 121, at G-4 (June 23, 1992).

n318 U.S. Treasury and Internal Revenue Service Report on the Application and Administration of Section 482 (April 9, 1992), reprinted in Daily Tax Rep (BNA) No. 70, at S-12 (April 10, 1992) [hereinafter Treasury Report].

n319 Id. at S-6.

n320 Id. at S-34.

n321 Wickham and Kerester, supra note 304, at 349.

n322 The economic evidence for undertaxation of multinationals is summarized in Tax Underpayments by U.S. Subsidiaries of Foreign Companies: Hearings Before the Subcomm. on Oversight of the House Comm. on Ways and Means, 101st Cong., 2d Sess. (1990). Further hearings providing information to this effect were held by the House Ways and Means Oversight Subcommittee on April 9, 1992, available in LEXIS, Fedtax Library, TNT File No. 92 TNT 77-22 (Apr. 10, 1992). See also, Harry Grubert et al., Explaining the Low Taxable Income of Foreign Controlled Companies in the U.S., in Studies in International Taxation 237, 247 (Alberto Giovannini et al. eds. 1993) (concluding a significant difference exists between the profits of multinationals and U.S. companies that cannot be explained by other factors); Treasury Report, supra, note 318, at S-11 (noting the data "does suggest that some FCCs may be underreporting income"); GAO, International Taxation, supra note 304 (observing the data contain "indicators of potential improper transfer pricing by FCCs," but no conclusive proof). 
n323 See H.R. Red 5280, 102d Cong., 2d Sess. section 304 (1992). This "Foreign Income Tax Rationalization and Simplification Act of 1992," as introduced by Reps. Rostenkowski and Gradison on May 28, 1992, sought to amend section 482 of the Code to require certain foreign-owned U.S. corporations to report income at levels comparable to U.S. owned competitors. Id. See also, Jeffrey H. Birnbaum, Clinton's Revised Economic Plan Sets Massive Tax Increases for Foreign Firms, Wall St. J., June 22, 1992, at A16.

n324 GAO, International Taxation, supra note 304, at 63.

n325 Id. at 62-63.

n326 Id. at 63.

n327 Id.

n328 The GAO report discusses five alternatives to the ALS but concludes "although we expect difficulties with arm's length pricing to continue, we can find no problem-free alternative that would dictate Treasury's abandoning its current course." GAO, International Taxation, supra note 304, at 93. The other four alternatives, other than formulary allocation, are expanded allocation methods (essentially, the CPM, which suffers from the administrative complexity of the ALS without advancing international consensus), expanded safe harbors (rejected as too favorable to the taxpayer), a shift to consumption-based taxation or a minimum tax on assets (both rejected as too radical a departure from incomebased taxation). Id.

n329 See supra text accompanying notes 47-50.

n330 GAO, International Taxation, supra note 304, at 68. The idea of a formulary method for dividing the international tax base is outlined at length by Wickham \& Kerester, supra note 304, at 258-59 and Wickham, supra note 17, at 13. It originated with Geoffrey Harley, International Division of the Income Tax Base of Multinational Enterprise: An Overview, 13 Tax Notes 1563, 1563 (1981). See also, Kathleen Mathews, Dolan, Pearlman Square Off over Arm's Length v. Formula Approach, 50 Tax Notes 1336 (1991); Will Formulary Approtionment Replace the Arm's Length Standard?, Tax Notes Today, March 26, 1993 (stating all but one speaker at a Congressional hearing agreed that the United States should abandon the ALS). See generally, sources cited supra note 9.

n331 On the unitary business controversy see Walter Hellerstein, State Taxation: Corporate Income and Franchise Taxes, ch. 8 (1983, supp. 1989), and, more recently, see Allied-Signal, Inc. v. Director, Division of Taxation, 504 U.S. 768 (1992).

n332 GAO, International Taxation, supra note 304, at 70. 
n333 See, e.g., I.R.C. section 267(b). A more flexible definition of "control" may be preferable for section 482 purposes.

n334 See Eugene F. Corrigan, Toward Uniformity in Interstate Taxation, 11 Tax Notes 507 (Sept. 15, 1980) (supporting a control only test for determining unitary business).

n335 See, e.g., Stanley I. Langbein, A Modified Fractional Apportionment Proposal for Tax Transfer Pricing, 54 Tax Notes 719 (Feb 10, 1992); Michael McIntyre, Design of a National Formulary Apportionment Tax System, A Paper Presented at the National Tax Association 84th Annual Conference on Taxation (1991).

n336 Rev. Proc. 91-22, 1991-11 I.R.B. 11.

n337 APAs for Barclays Bank and Sumitomo Bank, for example, took 18 months to negotiate. See, John Turro, I.R.S. Inks Two Pricing Agreements in Derivative Product Area, 55 Tax Notes 725 (May 11, 1992).

n338 Rev. Proc. 91-22 section 3, 1991-11 I.R.B. 11 (permitting application of any "fourth" method in the absence of comparables). The Barclays and Sumitomo APAs are based on formulary allocation (agreed upon with the U.K.). See I.R.S. Notice 94-40, 1994-17 I.R.B. 22 (describing formulary methods used in global trading cases).

n339 Id. On recent positive developments in the APA area, see, e.g., David Brunori, Advance Pricing Agreement Program is Getting High Marks, 63 Tax Notes 139 (April 11, 1994); IRS Provides APA Activity Update, 63 Tax Notes 290 (Apr. 18, 1994); Julianne Mackinnon, APAs Moving Toward Multilateral Approach, IFA Panelists Say, 65 Tax Notes 1333 (Dec. 12, 1994); Multinationals May Seek APAs in Response to Burdensome Penalty Regs, 66 Tax Notes 385 (Jan. 16, 1995); Michael Schwartz et al., Advance Pricing Agreements: Starting the Process, 65 Tax Notes 235 (Oct. 10, 1994); Michael Schwartz et al., Working with the APA Process, 63 Tax Notes 1359 (June 6, 1994); John Turro, Tax Administrators Reach Consensus on APA Guidelines, 65 Tax Notes 813 (Nov. 14, 1994) (reporting on agreement among Pacific Rim tax administrators); Stephen C. Wrappe, Advance Pricing Agreements: The IRS Rediscovers Alternative Dispute Resolution, 63 Tax Notes 1343 (June 6, 1994).

n340 This is the formula used by the U.S. in the case of sales of manufactured goods through a branch. See Treas. Reg. section 1.863-3(b)(2), Example 1 and Temp. Treas. Reg. section 1.863-3T(b)(2), Example 2. This type of formula has achieved international recognition in the most recent draft of the OECD Model treaty. See OECD Model (Income and Capital) Tax Treaty, art. 7(4), 1992.

n341 See, e.g., the formula agreed upon by the United States, Japan and the United Kingdom (the latter two are traditional opponents of formulary methods) for Barclays and Sumitomo banks, and summarized in I.R.S. Notice. 94-40, 1994-17 I.R.B. 22. See also, U.S. Treasury-IRS, Joint Statement of Policy and Action Plan on International Tax 
Compliance (Dec. 17, 1993), reprinted in Daily Tax Rep. (BNA) No. 242, at L-1 (Dec. 20, 1993) (in negotiating APAs, the Service will consider formulary methods where appropriate).

n342 See I.R.C. $\S \S 6038-6038 C$.

n343 GAO, International Taxation, supra note 304, at 93-94.

n344 Langbein, supra note 17, at 669-71. See U.S. Treasury and Internal Revenue Service, Report on the Application and Administration of Section 482, Appendix E (the Report of Agreed Discussions Between the Tax Administrations of France, Germany, the United Kingdom, and the United States) (April 9, 1992), reprinted in Daily Tax Rep. (BNA) No. 70, at S-44 (April 10 1992) (discussing the use of formulary methods by the United Kingdom, Germany and France).

n345 The vast majority of the states apply uniform allocation and apportionment rules. Twenty three have adopted the Uniform Division of Income for Tax Purposes Act (UDITPA). Hellerstein, supra note 331, at 496-97. Forty-four states follow the "Massachusetts Formula" of property, payroll and sales, and even specific rules for its application are largely uniform. CCH Tax Guide -- All States (1994), 1064-73; Hellerstein, supra note 331 at 618.

n346 Langbein, supra note 17, at 646-53.

n347 OECD Transfer Pricing Guidelines for Multinational Enterprises and Tax Administrators, 9 Tax Notes Int'l 155 (July 18, 1994). It surely is no accident this report was published just days after the promulgation of the final section 482 regulations.

n348 Brian J. Arnold and Thomas E. McDonnell, Report on the Invitational Conference on Transfer Pricing: the Allocation of Income and Expenses Among Countries, 61 Tax Notes 1377, 1381 (Dec. 13, 1993).

n349 A strong argument can be made that the adoption of formulary methods by the United States would not violate any treaty obligations. See Louis M. Kauder, The Unspecified Federal Tax Policy of Arm's Length: A Comment on the Continuing Vitality of Formulary Apportionment at the Federal Level, 60 Tax Notes 1147 (Aug. 23, 1993). 
POSTSCRIPT, 2006:

Twelve years have passed since the new transfer pricing regulations were issued in 1994. In general, these years have been marked by the unwillingness of either the taxpayers or the IRS to challenge directly the application of the new regulations. Instead, most of the activity has been either in the APA program, which has grown to over 600 APAs concluded by 2006, in the administrative appeals process, or relating to peripheral though important issues like cost sharing. As a result, it is hard to tell what impact the new regulations have had on transfer pricing litigation.

The transfer pricing cases litigated since 1995 fall into two periods. From 1995 to 2000 there were several cases litigated, all of which still fell under the old regulations, and most of which were taxpayer victories. Then there was a hiatus, with no reported cases between 2001 and 2005, followed by the first important decision on cost sharing in 2005.

The cases litigated in the period between 1995 and 2000 were under the old regulations and continued the trend of taxpayer victories in the transfer pricing area, although some split the difference between the IRS and the taxpayer. In Altama Delta Corp., the Tax Court applied the cost plus method under the 1968 regulations to transfer prices charged by a Puerto Rico based corporation electing the cost sharing method under sec. 936 which sold combat boot uppers to its US parent corporation, which manufactured and sold finished combat boots under a Department of Defense contract. ${ }^{2}$ The IRS attempted to limit the subsidiary to either a 15\% markup on its non material costs or to a $7.5 \%$ markup on all costs. The court rejected the government's argument on the grounds that the government's purported comparables were general footwear manufacturers, whereas the taxpayer was in the combat boot industry, which enjoyed higher profits in the years in question. The court also ruled that the government's attempt to apply operating profit rather than gross profit margins was unreasonable and was not a valid application of the cost plus method. The court generally accepted the taxpayer's application to the subsidiary of gross profit margins earned by others in the combat boot industry, but it limited the gross margin because the parent faced higher risks than the subsidiary.

Inverworld, Inc. v. Commissioner is generally considered an IRS victory because the case involved other issues relating to the US subsidiary of a Caymans corporation controlled by Mexican principals. ${ }^{3}$ However, the case also had a transfer pricing issue, and the Tax Court held that the IRS' method of allocating income to the US subsidiary was arbitrary and unreasonable and that the correct amount should be based on arm's length fees charged by the subsidiary to its clients.

DHL Corp. v. Comm'r was an important case involving intangibles. The taxpayer in 1992 sold to DHLI, its foreign affiliate, the worldwide rights to its trademark for $\$ 20$ million. At the same time, DHL sold 57.5\% of DHLI to three unrelated investors. ${ }^{4}$ The IRS argued that the arm's length price should have been $\$ 300$ million, while the taxpayer valued it at $\$ 50$ million. The Tax Court rejected both valuation estimates, and concluded that the value of the trademark was $\$ 150$ million, or $50 \%$ of the IRS valuation, and that $\$ 50$ million of that was associated with US rights and \$100 million with foreign rights. The Ninth Circuit affirmed on the valuation of the US rights, but rejected any adjustment for foreign rights because DHLI and not DHL was the owner of such rights under the 1968 regulations, since it incurred most of the expenses in developing such rights. Thus, the end result of a \$50 million adjustment was the same as the taxpayer's position and the case should be viewed as a significant taxpayer victory in the important are of intangible valuation.

GAC Produce Corporation illustrates that the IRS can win transfer pricing cases against small and medium taxpayers that do not have the litigating resources enjoyed by major multinationals. ${ }^{5}$ The case involved a corporate distributor of fresh produce and its controlled entities in Mexico, and the Tax Court held that the commissions received by the distributor for marketing services were below arm's length because they did not even cover its costs. The taxpayer position lost because it was extreme, and it is doubtful the case can be relied upon as evidence of an improvement in the IRS' litigation record.

In UPS v. Comm'r the taxpayer transferred its profits from excess valuation charges, which are premiums paid by customers for replacement of packages lost or damaged in shipping, to a Bermuda affiliate. ${ }^{6}$ The Tax Court rejected

\footnotetext{
${ }^{2}$ Altama Delta Corp. v. Comm’r, 104 TC 4241995.

${ }^{3}$ Inverworld, Inc. v. Comm’r, 71 TCM 32311996 and 73 TCM 27771997.

${ }^{4}$ DHL corp. v. Comm'r, 76 TCM 1122 1998, aff'd in part and rev's in part, 285 F.3d $12109^{\text {th }}$ Cir. 2002.

${ }^{5}$ GAC Produce Co., Inc. V. Comm'r, 77 TCM 18901999.

${ }^{6}$ United Parcel Service v. Comm'r, 78 TCM 262 1999, rev'd, 11th Cir.
} 
the transfer as a sham, because while the nominal transfer was to an unrelated party the ultimate risk and profit was to the related party, OPL. However, the Court of Appeals reversed, resulting in another significant taxpayer victory in the area of intangibles. The main rationale for the Court of Appeals decision was that the charges to unrelated customers were arm's length, but this does not explain why the significant profits should be deemed earned by OPL, rather than the taxpayer.

In Compaq v. Comm'r the taxpayer purchased about 50\% of its printed circuit assemblies from a Singapore subsidiary. ${ }^{7}$ The taxpayer set its prices on a modified cost plus basis, using US standard costs which were less than Singapore standard costs. The IRS rejected this method, but the Tax Court approved the taxpayer's position, and concluded that the notice of deficiency was arbitrary and capricious and that the prices should be upheld under CUP. The court accepted the taxpayer' allocation of location savings to the subsidiary and also declined to adjust the price for volume discounts because these were not required under the 1968 regulations.

After Compaq there are no final decisions in transfer pricing cases until 2005, when the first decision on cost sharing came down and was another major taxpayer victory. Cost sharing grew out of the super royalty rule that was enacted in 1986 to prevent royalty free transfers of intangibles to low tax subsidiaries. Under cost sharing, the taxpayer and its foreign affiliate can enter into an agreement to share the costs of developing an intangible in a prescribed ratio, such as 20 to $80 \%$. The low tax affiliate then pays for its share of the costs of development, $80 \%$ in this case, and as a result can book $80 \%$ of the resulting profit without being subject to IRS challenge or to the super royalty rule. Importantly, no research and development needs to actually take place in the low tax affiliate, which just has to pay for the costs with funds contributed by the parent. If the costs are $\$ 1$ million and the profit is $\$ 1$ billion, a not unreasonable assumption for pharmaceutical patents, the low tax affiliate can shelter $\$ 800$ million from tax at a cost of $\$ 800,000{ }^{8}$

The rationale behind the rule was that if the research and development is unsuccessful, the taxpayer gives up on the deduction of the costs allocated to the low tax affiliate, since it is a foreign source deduction. But it seems very generous to allow $\$ 800$ million to escape from tax at a potential risk of a $\$ 800,000$ deduction. In addition, taxpayers avoided even that risk by entering into the agreement only after the value of the research and development was already established, although then they had to argue with the IRS on the value of the "buy in" payment the affiliate had to make for the established value of the intangible.

The issue in Xilinx v. Comm'r was whether in calculating the cost to be included in a cost sharing agreement, the taxpayer had to include the cost of exercising stock options granted to employees who were performing the $\mathrm{R}$ and D. ${ }^{9}$ The Tax Court held that because cost sharing is covered by the ALS, the cost of options should not be included because unrelated parties would not have been willing to share the cost of the options. This case is a very pro-taxpayer result because the deduction of the option exercise frequently wipes out the US tax liability of high tech companies, so that as a result most of the profit from an intangible can remain offshore while the portion allocated to the US under the agreement is protected from tax by deducting the option exercise costs. The case once again illustrates how unrealistic it is to rely on the ALS because these agreements are usually not entered into between unrelated parties, and thus the cost sharing issuer does not arise.

The IRS has attempted to deal with some of the issues in these cases by issuing new regulations. It now has issued regulations on transfer pricing related to both services and intangibles, which are in general similar to the 1994 regulations, with some modifications. It has also recently proposed new cost sharing regulations that would eliminate the advantage of the method by requiring that if the low tax affiliate only contributes cash, it only gets a normal return on the cash, with the rest of the profit allocated to the parent. This is likely to eliminate the attractiveness of cost sharing if finalized.

Thus, the litigation record since 1994 has not in general favored the IRS much more than the pre-1994 record, although none of these cases except Xilinx were litigated under the new regulations. Some taxpayers are entering APAs, but these cover only a small part of the overall transfer pricing universe. Instead, most taxpayers appear to be taking a wait and see attitude until the first major case under the new regulations is decided.

${ }^{7}$ Compaq Computer Corp. V. Comm’r, 78 TCM 201999.

${ }^{8}$ Treas. Reg. 1.482/7.

${ }^{9}$ Xilinx Inc. V. Comm'r, 125 TC 372005. 
For a while, this case seemed likely to be Glaxo. Glaxo involved the proper allocation of the profit from selling the antacid drug Zantac in the US between the UK parent, Glaxo-Wellcome, which did the research and development and production, and its US affiliate, which did the distribution. The IRS argued that $50 \%$ of the profit should be allocated to distribution, while the UK claimed most of the profit relates to R and D and production.

If the IRS had won Glaxo, that would have helped drive reluctant taxpayers into the APA program, which is the best hope of resolving the transfer pricing mess in the absence of consensus on a formula. However, the IRS chose to settle, albeit for a hefty $\$ 3.4$ billion (out of about $\$ 10$ billion at stake). One can understand why, given the litigation record, but now we have to wait until the next big case.

In the meantime, however, there is some progress toward reaching consensus on a formula, albeit not in the US: The EU Commission has recently come out with a proposal for formulary apportionment as the basis for allocating profits of affiliated enterprises within the EU. If this proposal is adopted, it seems very likely that the US and other OECD members could adopt the same formula for their transfer pricing as the default rule, with APAs as the alternative if the taxpayer does not like the result. Only thus will the great transfer pricing dilemma be resolved. 